NBER WORKING PAPER SERIES

WAGE ADJUSTMENT IN THE GREAT RECESSION

Michael W. Elsby

Donggyun Shin

Gary Solon

Working Paper 19478

http://www.nber.org/papers/w19478

\author{
NATIONAL BUREAU OF ECONOMIC RESEARCH \\ 1050 Massachusetts Avenue \\ Cambridge, MA 02138 \\ September 2013
}

The authors are grateful for helpful comments from David Card, Henry Farber, Alexandre Mas, Jennifer Smith, and participants at the May 2013 NBER conference on labor markets and the Great Recession. The paper is based partly on data from the New Earnings Survey (Crown copyright 2012) originally created, funded, and deposited by the Office for National Statistics, and distributed under secure access by the UK Data Archive. Neither the Office for National Statistics nor the UK Data Archive bears responsibility for the accuracy, comprehensiveness, analysis, or interpretation of these data. Crown copyright material is reproduced with the permission of the Controller of HMSO and the Queen's Printer for Scotland. Elsby gratefully acknowledges funding from the Philip Leverhulme Prize granted by the Leverhulme Trust. The views expressed herein are those of the authors and do not necessarily reflect the views of the National Bureau of Economic Research, or the Leverhulme Trust.

NBER working papers are circulated for discussion and comment purposes. They have not been peerreviewed or been subject to the review by the NBER Board of Directors that accompanies official NBER publications.

(C) 2013 by Michael W. Elsby, Donggyun Shin, and Gary Solon. All rights reserved. Short sections of text, not to exceed two paragraphs, may be quoted without explicit permission provided that full credit, including $\odot$ notice, is given to the source. 
Wage Adjustment in the Great Recession

Michael W. Elsby, Donggyun Shin, and Gary Solon

NBER Working Paper No. 19478

September 2013

JEL No. E24,E32,J3,J64

\begin{abstract}
$\underline{\text { ABSTRACT }}$
Using 1979-2011 Current Population Survey data for the United States and 1975-2011 New Earnings Survey data for Great Britain, we study wage behavior in both countries, with particular attention to the Great Recession. Real wages are procyclical in both countries, but the procyclicality of real wages varies across recessions, and does so differently between the two countries. U.S. distributions of year-to-year nominal wage change show many workers reporting zero change (suggesting wage stickiness) and many reporting nominal reductions (suggesting wage flexibility), but both findings could be distorted by reporting error. The British data, which are based on employers' payroll records, show much lower prevalence of zero wage change, but still show surprisingly frequent nominal wage cuts. The complex constellation of empirical regularities defies explanation by simple theories.
\end{abstract}

Michael W. Elsby

University of Edinburgh

School of Economics

31 Buccleuch Place

Edinburgh

EH8 9JT

United Kingdom

Mike.Elsby@ed.ac.uk

Donggyun Shin

Department of Economics

Kyung Hee University

Seoul, Republic of Korea

dgshin@khu.ac.kr
Gary Solon

Department of Economics

Michigan State University

East Lansing, MI 48824-1038

and NBER

solon@msu.edu 


\section{Wage Adjustment in the Great Recession}

As of a quarter-century ago, the conventional wisdom among macroeconomists was that real wage rates are more or less non-cyclical, and many macroeconomic models described wage inflexibility as a key contributor to cyclical unemployment. Since then, however, numerous empirical studies based on microdata for workers have found that real wages are substantially procyclical. ${ }^{1}$ This procyclicality had been obscured in aggregate wage statistics, which tend to give more weight to low-skill workers during expansions than during recessions. As summarized by Martins, Solon, and Thomas (2012), the microdata-based literature has found that the cyclical elasticity of real wages is similar to that of employment.

Most of the U.S. microdata-based literature, however, is based on data extending no later than the early 1990s. An obvious question is what the cyclical wage patterns have been more recently. Most importantly, how have wages behaved during the Great Recession? Is there reason to think that wages responded especially sluggishly during this downturn and that stickiness of wages contributed to the Great Recession's high unemployment? ${ }^{2}$

This article addresses these questions with data for both the United States and Great Britain. Section I uses March Current Population Survey data to trace U.S. real wage behavior over the 1979-2011 period. Section II uses additional Current Population Survey data to explore the role of inflation and nominal wage stickiness. Section III presents parallel analyses for Great Britain based on data from the New Earnings Survey. Section IV summarizes and discusses our findings.

\section{Real Wages in the United States, 1979-2011}

Our U.S. analyses of real wages are based on the annual March Current Population Surveys (CPS). Every March CPS asks sample members about their annual earnings and

\footnotetext{
${ }^{1}$ Examples from the U.S. literature are Stockman (1983), Bils (1985), Solon, Barsky, and Parker (1994), Devereux (2001), Bowlus, Liu, and Robinson (2002), and Shin and Solon (2007). Similar studies for other countries include Devereux and Hart (2006) for Great Britain; Carneiro, Guimarães, and Portugal (2012) and Martins, Solon, and Thomas (2012) for Portugal; and Shin (2012) for Korea.

${ }^{2}$ For example, in a brief Federal Reserve Bank of San Francisco note entitled "Why Has Wage Growth Stayed Strong?" Daly, Hobijn, and Lucking (2012) concluded from aggregate wage data that "Real wage growth ... has held up surprisingly well in the recent recession and recovery," and also found that, "During the recent recession and recovery, the run-up in the fraction of workers subject to downward nominal wage rigidity has been especially large.... This may partly explain why real wage growth has not significantly declined since the onset of the recession in December 2007 and why hiring has been slow since the start of the recovery in mid-2009."
} 
employment in the preceding calendar year, so we can measure each worker's hourly wage in the preceding year as the ratio of annual earnings to annual hours of work. Relative to alternative U.S. data sets, the March CPS has three advantages. First, because the Bureau of Labor Statistics (BLS) generates the public use files quickly, we have access to recent data, up through the March 2012 CPS data for 2011 (and dating back in a comparable way to 1979). We therefore have good data for the Great Recession and its immediate aftermath, as well as for earlier recessions, including the similarly severe recession of the early 1980s. Second, the CPS provides large nationally representative samples. Our main analyses of real wages are based on well over 20,000 workers of each gender every year.

Third, access to the microdata goes a considerable way towards reducing the composition-bias issues associated with aggregate data such as the average hourly earnings series from the BLS employer survey. As discussed by Solon, Barsky, and Parker (1994) and others, such aggregate series are constructed as hours-weighted averages of workers' wages, so workers with more employment get greater weight in the statistics. It is well documented that low-skill workers' employment is especially sensitive to cyclical fluctuations, so low-skill workers get less weight in aggregate wage statistics during recessions than they do during expansions. This imparts a countercyclical bias in aggregate wage statistics, making workers' real wage opportunities appear less procyclical than they really are. Thanks to access to the CPS microdata, we can obtain a reliable hourly wage variable for every worker with substantial employment sometime during the calendar year, and we can weight those workers equally instead of weighting them by their annual hours. Unfortunately, though, we cannot avoid composition bias entirely. We cannot measure the wage opportunities of individuals with no work during the calendar year (and, as we will discuss in a moment, for data reliability reasons we also will exclude individuals with very few work hours over the calendar year). We will achieve a partial correction of the resulting composition bias by regression-adjusting our annual wage measures for some observable characteristics (education, potential work experience, and race) of the worker samples. Finally, for workers employed for only part of the year, we measure their wages when they were employed, but we do not observe their wage opportunities during the time they were not employed. Of course, this is an insoluble problem in every data set. 
To focus on worker groups with substantial attachment to the labor force, we restrict our real wage analyses to workers between the ages of 25 and 59. Because of extreme outliers (such as the man recorded as having over $\$ 400,000$ of earnings but only one hour of work in 2008!), we require at least 100 annual hours of work, and we also exclude the cases with the top 1 percent and bottom 1 percent of average hourly earnings. The CPS oversamples in less populous states, so for the sake of national representativeness, all our analyses use the provided sampling weights. Our real wage analyses include the imputed wage measures provided for the substantial number of cases with non-response for earnings. ${ }^{3}$

Table 1 displays men's mean and median log real wages by year. Results are shown for two deflators, the personal consumption expenditures (PCE) deflator from the national income accounts and the CPI-U-RS version of the consumer price index. Both are scaled to express real wages in 2009 dollars. Figure 1 adds a visual display of the real wage series based on the PCE deflator. The table and figure also show the annual unemployment rate, to emphasize which years are recession years and which are expansion years.

The first thing to note in Table 1 and Figure 1 is the stagnation of men's real wages over the 1979-2011 period. Real wages at the end of the period are much the same as at the beginning. Although this is bad news for us as male workers, it is convenient for us as researchers. With almost no secular trend, it becomes easy to discern cyclical patterns. (The subsequent analysis for women will be a little more nuanced.)

Like previous microdata-based studies, Table 1 and Figure 1 indicate that men's real wages are substantially procyclical. For example, from 1979 to 1983 , when the unemployment rate went from 5.8 to 9.6, the mean log real wage based on the PCE deflator fell from 2.933 to 2.889, a reduction of 0.044 (as also shown in Table 2, which provides a 0.005 standard error for the estimated change between 1979 and 1983). ${ }^{4}$ With the CPI-U-RS used as an alternative deflator, the estimated wage reduction of 0.057 is even larger. The recession of the early 1990s was much less severe, but still was associated with a large reduction in the mean log real wage. The recession of the early 2000s showed relatively little impact on the labor market, as reflected in either the unemployment rate or the mean log wage.

\footnotetext{
${ }^{3}$ Unweighted estimates turn out to be similar. Excluding observations with imputed wages results in higher mean and median wages, but has almost no effect on measured cyclical variation.

${ }^{4}$ If we mimic the composition bias in aggregate wage statistics by hours-weighting the CPS data, real wages then appear considerably less procyclical. For example, the 1979-83 drop in the log of the hours-weighted mean real wage based on the PCE deflator is only 0.010 .
} 
What interests us most, though, is the experience of the Great Recession. The unemployment rate, which was 4.6 in 2006 and 2007, reached 9.6 in 2010 and was still at 8.9 in 2011. Even though this run-up in the unemployment rate was even greater than that of the early 1980 s, the reduction in men's real wages was comparatively modest. The mean log real wage based on the PCE deflator was 3.007 in 2006 and 2007, had dropped to 2.993 by 2010, and declined slightly further to 2.989 in 2011 . Compared to the 0.044 reduction from 1979 to 1983 , the 0.018 reduction from 2006-2007 to 2011 was significantly smaller (in both the statistical and substantive senses). Similarly, with wages deflated instead by the CPI-U-RS, the 2006-2011 reduction in the mean log real wage was 0.026 , as compared to the 0.057 reduction of 1979 1983.

So far we have discussed means, but there is considerable merit in looking at medians as well. For one thing, medians are more robust to outliers. In fact, the medians stay the same regardless of whether we do or do not trim the top and bottom $1 \%$ of wage observations. Relatedly, medians sidestep the problem of earnings top-codes in the CPS. Before 1996, topcoded earnings observations were simply assigned the top-code threshold. Since 1996, a topcoded individual has been assigned the sample mean value among all cases above the threshold that share the individual's gender, race, and status vis-à-vis full-time/full-year work. As a result, our means of log real wages before and after 1996 are not altogether comparable. The medians, however, are comparable over time because they are unaffected by the treatment of top-codes.

As can be seen in Tables 1 and 2, our medians tell much the same story as the means. From 1979 to 1983, the median log real wage based on the PCE deflator decreased by 0.056, and the one based on the CPI-U-RS decreased by 0.069. In contrast, from 2006 to 2011, the one based on the PCE deflator decreased by only 0.026, and the one based on the CPI-U-RS fell by only 0.032. The medians, like the means, indicate that real wages are considerably procyclical, but the procyclicality of men's real wages has been significantly milder in the Great Recession than in the recession of the early 1980s.

The cyclical patterns in these mean and median wage series are subject to a countercyclical composition bias because our sample selection criterion requiring at least 100 annual hours of work disproportionately screens out low-wage workers during recessions. We can partially correct for that bias by controlling for year-to-year changes in the demographic composition of our samples. For example, as shown in Table 2, in addition to showing mean log 
wages for each year in the 1979-1983 period, we also estimate "regression-adjusted" year effects by applying least squares (again weighting by the provided CPS sampling weights) to a regression of individual workers' log real wages on year dummies for 1980, 1981, 1982, and 1983 (with 1979 as the omitted reference category) and controls for years of education, a quartic in potential work experience (age minus years of education minus 6), and race dummies. ${ }^{5}$ As expected, the regression-adjusted year effects show even more wage procyclicality. Whereas the unadjusted means indicate that log real wages were 0.044 lower in 1983 than in 1979, the adjusted 1983 year effect is 0.059 less than the 1979 effect.

We perform the same exercise for the 2006-2011 period. We estimate each period's regression separately because it is implausible that the coefficients of the control variables would come close to holding still over the entire 1979-2011 period. For example, our estimated coefficient of education is 0.072 (with estimated standard error 0.0005) for the 1979-1983 period, but it is $0.111(0.0004)$ for 2006-2011. Whereas the unadjusted means indicate that $\log$ real wages were 0.018 lower in 2011 than in 2006, the adjusted 2011 year effect is 0.032 less than the 2006 effect. Again, however, this wage drop in the Great Recession is significantly smaller than the wage decrease during the early 1980 s recession.

For the same reasons it was worthwhile to calculate medians along with means, it makes sense to estimate median regressions as well as mean regressions. In the last column of Table 2, we report the estimated year effects from applying weighted least absolute deviations to the regression of log real wages on year dummies and control variables. The results indicate again that men's real wages decreased during the Great Recession, but not as much as in the recession of the early 1980s.

In most instances, the regression adjustments indicate that accounting for observed heterogeneity reveals greater procyclicality in real wages. Presumably, accounting for unobserved heterogeneity would move further in the same direction. The traditional approach to accounting for unobserved heterogeneity in the microdata-based literature on real wage cyclicality is to control for worker fixed effects by tracking the same workers over time in a panel survey. Although the rotating panel design of the CPS makes it possible to follow a portion of one March's sample to the next March, the CPS is far from ideal for longitudinal

\footnotetext{
${ }^{5}$ We use the method of Jaeger (1997, last column of Table 2) to construct a consistent education variable over time. The race categorization we are able to construct for the full time period consists of three categories: white, black, and other.
} 
analysis. The sample sizes for March-to-March matches are almost always less than one-third of the sample sizes for the cross-sections. Worse yet, one of the sources of the sample loss is that the CPS does not follow residential movers, and exclusion of movers is an endogenous sample selection in a study of wage changes.

Nevertheless, as a further check on our results from repeated cross-sections, we perform year-to-year matches from our samples of workers between adjacent March Current Population Surveys. We follow the guidance of Madrian and Lefgren (2000) in verifying that longitudinal matches on identification numbers are true matches by requiring that gender and race also match, that year-to-year change in reported age is between -1 and 3, and that the respondent reports living in the same residence as in the previous March. We are able to match between most adjacent March surveys during our sample period, but not for 1985-1986 or 1995-1996 because of changes in household identifiers, and not for 1984-1985 because the residence question was not asked in 1985. We therefore cannot obtain longitudinal wage changes for 1983-1984, 19841985, or 1994-1995. For all other pairs of years in our sample period, the left side of Table 3 shows weighted sample means of men's year-to-year change in log real wages. ${ }^{6}$ We weight individuals by the simple average of their sampling weights across the two years.

The first thing to notice is that, because of normal life-cycle wage growth, the mean changes are almost always positive, and tend to be substantially positive in expansion years (for example, averaging about 0.03 from 1985 to 1989 and about 0.04 from 1995 to 2000). In stark contrast, the longitudinally matched men experienced virtually zero average real wage growth during the recessions of the early 1980s and early 1990s. Again, as we observed in our previous analyses, the mild recession of the early 2000s had little impact on the labor market. Finally, over the years 2006-2011, real wage growth averaged about 0.01, less than in typical expansion years, but more than in the recessions of the early 1980s and early 1990s. Thus, as in our analysis of repeated cross-sections, men's real wages continued to follow a procyclical pattern in the Great Recession, but to a lesser extent than one might have expected from earlier recessions.

Table 4 shows mean and median log real wages by year for women, as Table 1 did for men. And Figure 2 provides a visual display for women, as Figure 1 did for men. Where Table 1 and Figure 1 documented stagnant real wages for men, Table 4 and Figure 2 corroborate the

\footnotetext{
${ }^{6}$ We also have tried estimating regressions with controls for polynomials in age or potential experience, but the variation over time in the estimated year effects is virtually identical to that for the unadjusted means shown in Table 3.
} 
well-known rise in women's wages during the 1979-2011 period. All our measures suggest that, over the period as a whole, women's real wages rose at a rate of close to 0.10 per decade.

This upward secular trend in women's wages makes it trickier to distill the cyclical patterns. Nevertheless, inspection of Table 4 and Figure 2 reveals a clear tendency for women's real wages to rise more slowly during recessions. And in the Great Recession in particular, women's real wage growth appears to have stalled out completely. The relatively large effect that the Great Recession appears to have had on women's wages stands in contrast to its effect for men, which was smaller than in the recessions of the early 1980s and early 1990s. But a conclusive judgment on this will require additional years of data because a possible reading of Figure 2 is that women's real wage growth was starting to peter out before the Great Recession. If the upward trend in women's wages resumes in the years to come, the cyclical impact of the Great Recession will appear large. If it does not resume, the stalling-out will be interpreted instead as a change in secular trend.

Table 5 highlights the effects of the two most severe recessions on women's wages, as Table 2 did for men's wages. In addition to showing the relative movements in mean and median log wages, the table also presents regression-adjusted series that account for variation in the samples' education, potential experience, and race. As in Table 2 for men, these adjustments suggest even greater procyclicality in real wages. After adjustment, there appears to be virtually no real wage growth for women during the recession of the early 1980s, and negative growth during the Great Recession.

The right side of Table 3 shows the mean year-to-year changes in log real wages for women longitudinally matched between adjacent March Current Population Surveys. The combination of life-cycle wage growth and the upward secular trend in women's wages causes the mean log change to be positive in every single year. In 20 of the 29 pairs of years that can be matched, the growth rate in real wages is higher for women than for men. Again, the procyclicality of women's real wages is manifested as a tendency for slower growth in recession years than in expansion years. All four of the smallest increases in women's real wages are in recession years, three of them in the Great Recession.

To summarize, our evidence for 1979-2011 from March Current Population Surveys corroborates and updates the findings from earlier microdata-based studies that real wages in the United States are substantially procyclical. For men, however, we find that real wages took a 
smaller hit in the Great Recession than might have been expected from the experience of earlier recessions. Our results for women are less clear-cut because of the confounding of cyclical and trend variation, but a tentative impression is that women's real wages may have taken a relatively large hit in the Great Recession.

\section{Nominal Wages and Inflation in the United States}

The previous section discussed the mean log real wage series plotted for men in Figure 1 and for women in Figure 2. Of course, the mean log real wage is the difference between the mean log nominal wage and the log of the price level (measured in these figures with the PCE deflator). Both of these component series are plotted in Figures 3 and 4 along with their difference, the same log real wage series already plotted in Figures 1 and 2. The scale for the two log wage series is on the left axis, and the scale for the log deflator is on the right axis.

In both Figure 3 for men and Figure 4 for women, nominal wages grow substantially over time. In the case of men, long-run nominal wage growth is similar to the growth in the price level, so real wages show little secular trend. For women, nominal wage growth exceeds price inflation, so real wages trend substantially upwards.

As discussed in the previous section, men's real wages declined considerably during the recessions of the early 1980s and early 1990s. Figure 3 shows that nominal wages grew during those recessions, but more slowly than the price level. In the Great Recession, men's real wages seemed to decline less and more belatedly than in the recessions of the early 1980s and early 1990s. Nominal wages grew very little, but so did the price level. In 2009, when the unemployment rate was 9.3 percent, inflation as measured by the annual PCE deflator was virtually zero (and was slightly negative according to the CPI-U-RS). With no decline in nominal wages that year, real wages did not decline either. After 2009, inflation ran at about 2 percent a year, and the even smaller growth in nominal wages meant that real wages declined a little.

As also discussed in the previous section, the upward secular trend in women's real wages makes the discernment of cyclical patterns somewhat more challenging. In the recessions

of the early 1980s and early 1990s, women's real wages grew, but more slowly than in the expansions of the late 1980s and late 1990s. During the Great Recession, women's real wage growth stalled out altogether, seemingly implying a larger cyclical impact on real wages. A clear 
separation of the cyclical and trend movements, however, will have to await more years of data in the aftermath of the Great Recession.

At least for men, that the Great Recession appeared to reduce real wages less and more belatedly than in previous recessions suggests a possible role for the inflationary environment. At the outset of the recession of the early 1980s, inflation was unusually high, and employers could reduce real wages substantially even while granting nominal wage increases. This was still somewhat true in the recession of the early 1990s, when annual inflation was about 4 percent. But during the Great Recession, especially in 2009, the inflation rate was lower, and substantial real wage cuts would have required nominal wage cuts. Economists going back at least to Keynes (1936) have suggested that resistance to nominal wage cuts can constrain the response of real wages to slack labor demand, and that this wage stickiness might exacerbate rising unemployment during recessions.

This possibility that downward stickiness in nominal wages can impede wage adjustments to negative labor demand shocks has led numerous researchers (for example, McLaughlin, 1994; Card and Hyslop, 1996; Kahn, 1997; Altonji and Devereux, 1999; Elsby, 2009; and Daly, Hobijn, and Lucking, 2012) to examine longitudinal microdata to assess the prevalence of nominal wage stickiness in the United States. Because it is obvious that job changers typically experience wage changes, most of these researchers have focused on the more interesting question of whether workers staying with the same employer appear to experience nominal wage stickiness. What would be more interesting still would be to ascertain how many workers lose their jobs and become unemployed because of downward stickiness in nominal wages, but no one knows how to do that. Instead, the implicit assumption in this literature is that, if downward rigidity in nominal wages is sufficiently common to cause a lot of job losses, it also should be common among workers that stay employed with the same employer. In this section, we use longitudinally matched data from Current Population Surveys to extend this literature and update it to include the Great Recession.

Our analysis begins with the Current Population Surveys of January 1981, January 1983, January 1987, January 1991, February 1998, February 2000, January 2002, January 2004, January 2006, January 2008, January 2010, and January 2012. Each of these waves of the CPS included a job tenure supplement, which enables us to determine whether a worker had been 
employed for at least a year with the worker's current main employer. ${ }^{7}$ We focus on such workers in their eighth (and last) month in the CPS because workers in that "rotation group" also were asked to report their current nominal wage rate. Using nearly the same method for longitudinal matching described in Section I, we matched these workers to their data in the CPS one year earlier, when these workers were in their fourth month in sample. ${ }^{8}$ The fourth rotation group is the other "outgoing" rotation group asked to report a current nominal wage rate, so we are able to obtain an empirical distribution of year-to-year nominal wage growth of stayers for January 1980-January 1981, January 1982-January 1983， .., January 2011-January 2012. Fortunately, these matches include at least one year-to-year change from every recession from the 1980 s on, as well as several expansion years. ${ }^{9}$

Like many previous studies, we present histograms of the empirical distribution of yearto-year nominal wage changes. Our sample for each year-to-year match pools women and men between the ages of 16 and 64 in both years. We exclude observations for which wages were imputed on account of non-response. As in our analyses of real wages, we use the provided sampling weights to adjust for the Current Population Survey's oversampling of less populous states (though, in practice, this turns out not to affect the results much).

For each year-to-year match, we display two histograms - one in Figure 3 for workers paid by the hour in both years, and one in Figure 4 for workers not paid by the hour in either year. For the former, we use the reported hourly wage rate. For the latter, we follow Card and Hyslop (1996) in using the reported usual weekly earnings. In Card and Hyslop's words, "In principle, we can construct an hourly wage for non-hourly-rated workers by dividing usual weekly earnings by usual weekly hours. However, any measurement error in reported hours will lead to excessive volatility in imputed hourly wages." The typical sample size for each of our histograms is about 1,000 workers. Accordingly, the typical standard error for the estimated

\footnotetext{
${ }^{7}$ The appendix in Farber (2008) provides a valuable summary of the availability and content of CPS job tenure supplements over time.

${ }^{8}$ The one difference is that, in the current section's match, we do not use the question about living in the same residence as a year ago. That question is asked only in the March CPS.

${ }^{9}$ Card and Hyslop (1996) and Daly, Hobijn, and Lucking (2012) also use longitudinally matched CPS data to measure nominal wage change distributions, Card and Hyslop for 1979-1993 and Daly et al. for 1980-2011. Unlike us, they use all CPS months, not just those with job tenure supplements. As a result, they have many more observations, but their identification of stayers assumes that workers staying in the same industry and occupation also stayed with the same employer.
} 
percentage of workers with exactly zero nominal wage change from one January or February to the next is about one percentage point.

Each of our histograms features a thin spike at zero, which shows the percentage of the workers that reported the exact same wage in both years. For the hourly workers, in some years we display a pink segment of the zero spike, which represents workers whose wage was at the national minimum wage in both years. The relative value of the minimum wage became so low during our sample period, however, that there are no such cases in many years. The next bin to the right of the zero spike contains workers whose change in log nominal wage was positive but no greater than 0.02; the next bin contains those whose change in log nominal wage was greater than 0.02 and less than or equal to 0.04 ; etc. The bins to the left of zero are constructed symmetrically. To limit the histograms to a readable scale, we pile up workers with change in log nominal wage greater than 0.64 in the rightmost bin and those with change less than -0.34 in the leftmost bin. Some of the salient statistics from the histograms are summarized in Table 6.

In general, our histograms display several features noted by previous authors. First, there always $i s$ a spike at zero. As shown in Table 6, for each type of worker in each pair of years, a non-trivial minority of workers - ranging between 6 and 20 percent - reports the exact same nominal wage in both years. It is unclear in which direction these estimates are biased by reporting error. On one hand, a worker with the same true nominal wage in both years may be recorded as changing wages if the worker misreports the wage in either year. On the other hand, a worker with a modest wage change may round to the same number in both years and thus appear to have zero wage change. For example, a worker whose true nominal hourly wages were $\$ 19.80$ last year and $\$ 20.30$ this year may report an hourly wage of $\$ 20$ in both years. As will be discussed in the next section, studies of nominal wage stickiness in Great Britain have exploited richer data to suggest that the latter bias may dominate.

Second, the distribution of nominal wage changes is always centered on positive nominal wage growth. This is to be expected both because of keeping pay raises up with price inflation and because of exceeding price inflation in order to achieve normal life-cycle growth in real wages.

Third, there is always a non-trivial fraction of workers reporting nominal wage reductions. As shown in Table 6, this fraction always exceeds 10 percent for hourly workers and always exceeds 20 percent for non-hourly workers. Again it is unclear what proportion of these 
cases is an artifact of reporting error, but again the next section's discussion of British evidence will be instructive.

An advantage of having these distributions for many years is the opportunity to relate the patterns to variations in the economic environment. In particular, there is good reason to expect the distributions to be affected by both business cycle conditions and the inflation rate. We can illustrate with a very simple model. Suppose that workers always stay employed with the same employer and that, in the absence of any tendency towards nominal wage stickiness, the process determining worker $i$ 's real wage growth between years $t-1$ and $t$ would be

$$
\Delta \log \left(W_{i t} / P_{t}\right)=\beta_{0}+\beta_{1} C_{t}+\varepsilon_{i t}
$$

where $W_{i t}$ is the worker's nominal wage rate, $P_{t}$ is the price level, $C_{t}$ is a measure of business cycle conditions, $\beta_{1}>0$ if both $C_{t}$ and real wage growth are procyclical, and, conditional on $C_{t}$ and $P_{t}, \varepsilon_{i t}$ is normally distributed with mean zero and variance $\sigma^{2}$. Then the probability that the worker's nominal wage growth would be negative would be the probit function

$$
\begin{aligned}
\operatorname{Prob}\left(\Delta \log W_{i t}<0\right) & =\operatorname{Prob}\left(\varepsilon_{i t}<-\beta_{0}-\Delta \log P_{t}-\beta_{1} C_{t}\right) \\
& =\Phi\left[-\left(\beta_{0} / \sigma\right)-(1 / \sigma) \Delta \log P_{t}-\left(\beta_{1} / \sigma\right) C_{t}\right]
\end{aligned}
$$

where $\Phi($ ) is the standard normal cumulative distribution function. Now add the further extreme assumption that, because of downward rigidity of nominal wages, everyone that otherwise would have negative wage growth instead has zero nominal wage growth. Then the proportion of workers with zero nominal wage growth would be the probit function above, which clearly is negatively related to both the inflation rate and the business cycle indicator. Although the model is extreme, it does give a clear illustration of why many would expect the spike at zero in the histograms to be highest when inflation is low and the economy is in recession.

Indeed, Table 6 and the histograms show that there is something to that expectation. The highest spikes do appear during the Great Recession, when unusually weak demand coincided with a low inflation rate. The lowest spike appears in 1980-1981, when the inflation rate was about 10 percent and unemployment was rising but had not reached the high level of 1982-1983. 
In addition, there appears to be somewhat of an upward secular trend in the frequency of zero nominal wage change, which conceivably might be a gradually evolving response to a prolonged stretch without high inflation. ${ }^{10}$

Taken at face value, the finding of a spike at zero nominal wage change seems to suggest some degree of nominal wage rigidity, while the finding of a substantial fraction of nominal wage reductions seems to suggest a degree of nominal wage flexibility. We will defer further discussion of the extent to which both patterns may reflect measurement error to the next section, in light of that section's richer evidence from Great Britain. Assuming for now that the evidence in our histograms is accurate, what is the economic significance? First, how would the distribution of wage growth differ in the absence of nominal wage stickiness? Second, whatever that difference is, what are the effects on quantity variables like employment and unemployment? In particular, has downward nominal wage rigidity been a major cause of the Great Recession's unusually high unemployment?

On the first question, we note that the spikes at zero nominal wage change that we measure during the Great Recession are only moderately greater than the ones we measure for earlier in the 2000s. Beyond that, it is remarkably difficult to identify how nominal wage growth distributions are affected by nominal wage stickiness. As noted earlier in this section, many excellent researchers have tackled this question before, but we are struck by how unsuccessful they have been in reaching definitive conclusions. A particularly sophisticated effort is the wellknown study by Kahn (1997), which used substantial changes in inflation over the 1970-1988 period to try to identify how nominal wage stickiness affected the distribution of wage growth across 12 one-percentage-point bins on either side of each year's median wage growth. Although the approach seems conceptually promising, it delivers only two robust findings - that there is a noticeable spike in the bin for zero nominal wage growth, and that there appears to be a dip in the bins for one or two percent above zero (which, as we will discuss in the next section, also could be a reporting effect, not a real phenomenon). All the other patterns of interest turn out to be sensitive to functional form specification or sample selection. For example, Kahn's

\footnotetext{
${ }^{10}$ These patterns are broadly consistent with those reported in the CPS analyses by Card and Hyslop (1996) and Daly, Hobijn, and Lucking (2012), but two differences stand out. First, unlike Card and Hyslop and ourselves, Daly et al. divide reported weekly earnings by reported weekly hours to get their nominal wage measure for non-hourly workers. As expected, this leads to considerably smaller spikes at zero nominal wage change. Second, for hourly workers, Daly et al. estimate a substantial dip in the frequency of zero nominal wage change in the years preceding the Great Recession. In contrast, our estimates in Table 6 do not show a drop-off after 2003-2004.
} 
results (nicely summarized in her Table 2) indicate a tendency away from nominal wage reductions for hourly workers, but show the opposite tendency in some specifications for nonhourly workers. Her estimates also indicate a dip in the bin for one percent below zero for nonhourly workers, but show no such dip for hourly workers. In the end, as is so often the case, inferring convincingly clear-cut counterfactual distributions from observational data turns out to be beyond the reach of even the most skillful researchers. ${ }^{11}$

If nothing else, though, there is the spike at zero. Assuming that is not merely an artifact of rounding error, we are led to the second, even harder question: What are the effects of the implied nominal wage inertia on employment and unemployment? Here it is helpful to make a distinction between workers in the "primary" and "secondary" sectors of the labor market. Our histograms pertain to workers that stayed with the same employer for at least a year. These tend to be the primary-sector workers, for whom various types of specific human capital foster longterm employment relationships. The histograms tend to exclude workers in the secondary sector, where specific human capital is mostly absent and labor turnover is high. There is little theoretical reason to expect wage rigidity in the secondary sector, and Bewley's (1999) anecdotal evidence from extensive interviews with employers during the recession of the early 1990s corroborates the expectation of wage flexibility in the secondary sector.

On the other hand, Bewley's interviews also dovetail with the zero spike's quantitative suggestion that primary-sector employers are reluctant to cut incumbent workers' nominal wages. But a long history of economic analysis, dating back at least to Becker (1962), questions whether current wages in long-term employment relationships are "allocative." Rather, current wages can be seen as installment payments within a longer-term compensation package. In particular, an employer's decision about whether to continue to employ the marginal incumbent worker should depend on the employer's beliefs about the present discounted value

$$
V=\sum_{t=1}^{T}\left\{\left(m_{t}-w_{t}\right) /\left[(1+r)^{t-1}\right]\right\}
$$

\footnotetext{
${ }^{11}$ We salute Kahn for reporting her sensitivity analyses in sufficient detail to make clear which results are and are not robust.
} 
where $m$ denotes the real value of the worker's marginal product, $w$ is the worker's real wage, $t$ indexes time period with the current period denoted as $t=1$, and $T$ is the worker's remaining tenure with the employer if not laid off this period. Of course, the latter is not only uncertain, but also endogenously determined by the employer's wage policy and future retention decisions. For simplicity, the real interest rate $r$ is assumed to be constant over time, and the worker's employment with the firm is assumed to be binary with no hours variation at the intensive margin. Now suppose that downward rigidity in the nominal wage causes the employee's current real wage $w_{1}$ to exceed her current real value of marginal product $m_{1}$. Even so, it is in the employer's interest to retain the employee as long as continuing her employment is profitable in present-value terms. Consequently, even in the face of evidence that there exists some stickiness in current nominal wages, it does not follow that such wage stickiness necessarily must generate inefficient job separations.

This theoretical point is buttressed by at least two pieces of empirical evidence. First is the anecdotal evidence from Bewley's interviews. On the question of why employers did not save laid-off workers' jobs by cutting their wages instead, here is Bewley's summary (pp. 1801): "I was surprised to learn that most managers did not believe that pay cuts would prevent many layoffs.... A common reaction to the question was puzzlement. Pay cuts would create little or no extra work and so would barely reduce the number of excess workers." The direct quotations from owners and managers include these (p. 185): "If I cut pay instead of laying people off, I would have lots of people with nothing to do." "What do pay cuts have to do with layoffs? A layoff is used when you don't have sufficient work for certain skills. What would you do with the extra help?" "Wage cuts are not an alternative to layoffs. You can't have a lot of people standing around doing nothing." Whatever else one makes of these statements, they are consistent with the proposition that downward stickiness in current nominal wages need not be a major source of economically inefficient layoffs.

Second, returning to the Great Recession in particular, if current wages are indeed allocative and downward nominal wage rigidity was especially binding in the Great Recession's low-inflation environment, one would expect the Great Recession to be characterized by an extraordinary burst of layoffs. The behavior of the quantity side of the U.S. labor market during the Great Recession has been documented in detail by Elsby, Hobijn, and Sahin (2010). They show that, while layoffs rose sharply during the recent downturn, the magnitude of the rise was 
comparable to that seen in prior severe recessions, notably the high-inflation environment of the early 1980s (see, for example, their Figure 9).

Instead, the most distinctive feature of the Great Recession with respect to labor quantities has been the extraordinarily long duration of unemployment spells. Therefore, understanding the high unemployment of the Great Recession requires understanding not only why some employers laid off so many workers into unemployment, but also why other employers have been so slow to hire the unemployed. Again, we find it instructive to consider the present-value expression in equation (3), except that now we regard it as the present value of a prospective new hire. ${ }^{12}$ Presumably, one major reason for employers' reluctance to hire the unemployed during a recession is that depressed product-market demand reduces prospective hires' current and near-term values of $m$. Even so, if current and future values of $w$ fell sufficiently, hiring the unemployed could become attractive to employers.

Accordingly, several recent papers - such as Shimer (2004), Hall (2005), Hall and Milgrom (2008), Gertler and Trigari (2009), and Kennan (2010) - have appended various sorts of hiring-wage stickiness to the Mortensen-Pissarides (1994) matching model in an effort to generate realistically large cyclical fluctuations in unemployment. Of course, it is always possible theoretically to generate more unemployment by assuming inflexible wages, but is the assumed inflexibility in hiring wages realistic? It is surprisingly difficult to answer that question because most countries have no publicly available data that track hiring wages within particular jobs within particular firms. Martins, Solon, and Thomas (2012) use such data from the Portuguese census of employers and find that real hiring wages in Portugal have been quite procyclical. Their conclusion, however, acknowledges that the initial hiring wage by itself is not a sufficient statistic for the relevant labor price. Referring again to equation (3), suppose that the initial hiring wage $w_{1}$ drops considerably in a recession, but this bargain price for labor vaporizes quickly because, as the recession passes, the cheaply hired workers either quit (small $T$ ) or are retained at the cost of substantial wage increases (high $w_{t}$ for $t>1$ ). In that case, even a substantial drop in initial hiring wages might not raise $V$ enough to induce primary-sector employers to hire from the unemployed. On the other hand, as emphasized by Kudlyak (2009),

\footnotetext{
${ }^{12}$ Following Becker (1962), the version of equation (3) for new hires should subtract off the part of hiring and training costs borne by the employer (and not borne by the worker through wage reductions), but that modification does not alter our main points.
} 
if instead workers hired at a low wage during a recession are somehow locked into a long-term employment relationship at a persistently low wage, the labor cost relevant to employers' recruiting decisions could be as cyclical as, or even more cyclical than, the initial hiring wage. Therefore, assessing the practical relevance of the new theories based on inflexible hiring wages will require more empirical work that, in the tradition of Beaudry and DiNardo (1991), recognizes the durability of primary-sector employment relationships and studies how wage paths in those relationships depend on current, past, and anticipated business cycle conditions. By the same token, future theoretical research needs to analyze the nature of implicit contracts in long-term employment relationships and consider how contracts for new workers interact with ongoing contracts for incumbent workers. In our view, the model of Snell and Thomas (2010) is a promising step in that direction.

In any case, we are skeptical that a theory of downward rigidity in nominal wages in particular is the key to understanding depressed hiring during the Great Recession. We already have noted that whatever such rigidity there is did not cause a greater upsurge in layoffs than occurred in the high-inflation environment of the early 1980s recession. While models such as the Snell-Thomas one recognize the possibility of spillovers from wage stickiness for incumbent workers to stickiness in hiring wages, it is hard to imagine that nominal rigidity is more constraining for new hires than for incumbents. Therefore, given that nominal rigidity did not appear to cause an unusually large upsurge in layoffs of incumbents, it seems implausible that it could account for the Great Recession's unusually long duration of unemployment spells.

To summarize, at an early stage of our research project, we were intrigued by the possibility that the combination of downward nominal wage rigidity with low inflation might be an important part of explaining the Great Recession's high unemployment. With some disappointment, we have come to feel that much of the evidence lines up poorly with that story. Although men's real wages seem to have taken a smaller hit in the Great Recession than in earlier recessions, women's wages seem to show the opposite pattern; although the histograms show a spike at zero nominal wage change, they also show many nominal wage cuts; the zero spike increased in the Great Recession, but not dramatically; and layoffs were not dramatically more prevalent in the Great Recession than in earlier severe recessions.

None of this is to deny the obvious - that the Great Recession has been a terrible economic downturn with painful consequences for many workers. Rather, we are saying that the 
existence of some nominal wage stickiness is not in itself prima facie evidence that such wage stickiness has caused an epidemic of economically inefficient choices by employers and employees. It is conceivable that the high unemployment of the Great Recession would have been nearly as high even in a parallel universe with absolutely flexible wages.

\section{Wages in Great Britain, 1975-2011}

Our analyses of real and nominal wages in Great Britain are based on the New Earnings Survey (NES, Office for National Statistics). These are the same data used by Devereux and Hart (2006) to study real wage cyclicality and by Nickell and Quintini (2003) to study nominal wage rigidity. Devereux and Hart's sample period ends at 2001, however, and Nickell and Quintini's ends at 1999. We are able to update both analyses to 2011.

Besides the obvious substantive merit of studying wage adjustment in Great Britain in addition to the United States, there is a methodological bonus - the NES data are superior to available U.S. data in several ways. First, the NES sample sizes are large. The survey is based on a one-percent sample of British income taxpayers, defined by individuals whose National Insurance numbers end in a given pair of digits. The resulting sample covers about 160,000 workers each year. Second, since the sample frame consistently has been based on the same pair of National Insurance number digits, the survey naturally has a panel structure. Third, the survey's wage information is unusually accurate. The survey is administered to employers, which are required by law to respond to the survey. The information on earnings and work hours elicited from the employers pertains to payroll information for a reference week in April. Because the earnings and hours data come from payroll records, they are thought to be much more accurate than similar data gathered from household surveys. A noteworthy limitation of the survey, however, is that it samples from taxpayers registered in the income tax system and therefore is thought to under-represent low-paid workers.

To provide context for our analysis, the two panels of Figure 7 respectively display the 1975-2012 U.K. series for the unemployment rate (as measured by the Labour Force Survey) and

the inflation rate (as measured by the change in the logarithm of the RPIX, which is based on the Retail Price Index, but excludes mortgage interest payments). To conform to the April timing of the NES, we use April measures for the unemployment rate and the RPIX. As the unemployment rate shows, our sample period encompasses three recessions. Like the United 
States, the United Kingdom experienced a very severe recession in the early 1980s. The somewhat less severe episode in the early 1990s again brought the unemployment rate to double digits. By some stroke of good fortune, the United Kingdom escaped the global contraction in the early 2000s, but was not spared in the Great Recession. Interestingly, although the output fall associated with the Great Recession was relatively large, the unemployment rate did not go as high as it had in the recessions of the early 1980s and early 1990s.

As the second panel of Figure 7 shows, the United Kingdom entered the 1980s with even higher inflation than the United States, reaching in excess of 20 percent on an annual basis. Subsequently, inflation fell rapidly in the 1980s and, except for an aberration in the late 1980s (associated with the boom at that time), remained below 5 percent per annum from 1985 through to the early stages of the current recession. Importantly, though, the rate of price inflation did rise during the Great Recession, exceeding 5 percent in 2010.

We will analyze real wages in part A of this section and nominal wages in part B. Throughout, our nominal wage measure is the worker's gross hourly earnings (defined as earnings divided by hours in the reference week in April) excluding overtime. For the analysis of real wages, we convert the nominal wage into 2012 pounds based on the April RPIX. In our initial sample selection, we exclude individuals who reported wages for more than one job in the reference week, who lost pay due to absence in that week, or who were younger than 16 or older than 64 , and then we trim the remaining sample for each year by excluding the cases with the top and bottom $1 \%$ of wages.

\section{A. Real wages}

Following our U.S. analysis of real wages, we further restrict the sample to workers between the ages of 25 and $59 .{ }^{13}$ The resulting sample of men is typically about 60,000 per year. The women's sample starts at more than 30,000 in 1975 and exceeds 60,000 in the later years of the sample period.

Our main analysis of U.S. real wages used repeated cross-sections from the March CPS that measured wages with average hourly earnings over the entire preceding calendar year. We also reported longitudinal results based on March-to-March matches, but with some reservation

\footnotetext{
${ }^{13}$ We have verified, however, that the cyclical patterns remain much the same if we use a 16-64 age range and also if we do not trim the outliers.
} 
on account of imperfections in the CPS as a source of longitudinal data, especially its failure to follow residential movers. Somewhat in parallel, we will begin by analyzing repeated crosssections from the NES, but with a caveat. Because the NES measures wages only for those working in the reference week in April, it seems potentially subject to more severe composition bias than the March CPS. Fortunately, however, the NES is an excellent source of longitudinal data, so we will proceed to longitudinal analyses that hold composition constant by following the same workers from one April to the next.

Starting with the repeated cross-sections, Table 7 shows mean log real wages by year separately for men and women, and Figure 8 displays both series visually. In Great Britain, as in the United States, the upward trend in women's wages is dramatic. But whereas men's wages stagnated in the United States, they have risen considerably in Great Britain, though not nearly as much as women's.

The cyclical patterns for men and women look similar, so we will discuss them together. The most striking cyclical setback to real wages occurred during the Great Recession. From 2008 to 2011, as the unemployment rate went from 5.2 to 7.8, men's real wages declined by about $10 \log$ points, and women's declined by about 6. Viewed against the backdrop of the upward secular trends in real wages, these reductions look all the more striking. The only other prominent reduction in real wages during our sample period occurred in the non-recession year of 1977. The story behind this episode appears to be related to incomes policies negotiated between the British government and the trade unions at that time. The agreement placed an upper bound on increases in nominal wages for that year, presumably in an attempt to curb inflation by stemming wage inflation. Despite this, price inflation remained very high, and so workers experienced real wage cuts.

Turning to the other recessions, during the early 1980s, when the unemployment rate rose to almost 12 percent and inflation was even higher than in the United States, real wage growth hardly slowed at all. The recession of the early 1990s was accompanied by a more noticeable slowing of real wage growth, but nothing like the reduction during the Great Recession. Thus, the British variation in wage cyclicality across recessions is more or less the opposite of what we measured for U.S. men in Section II. This poses still another challenge to simple stories about the interaction of downward nominal wage rigidity and the inflationary environment. In Great 
Britain, real wages took a much bigger hit in the Great Recession than in the early 1980s even though the early 1980s were a period of much higher inflation.

All of this, however, is based on wage measures from repeated cross-sections for a reference week in April. The U.S. evidence indicates that such measures could be subject to a substantial countercyclical composition bias, so we follow Devereux and Hart (2006) in using the longitudinal nature of the NES to hold worker composition constant by following the same workers from one April to the next. This longitudinal matching loses some workers not employed in one reference week or the other, but the sample sizes are still large. The men's sample size per year is usually over 50,000. The women's sample size starts at over 20,000 in 1975-1976 and reaches over 60,000 in 2010-2011.

Table 8 shows mean year-to-year change in log real wages by gender for each pair of years from 1975-1976 to 2010-2011. ${ }^{14}$ Figure 9 plots this longitudinally based series for each gender along with the first difference of the cross-sectional mean log wage series previously shown in Table 7 and Figure 8. Figure 9 vividly depicts two patterns. First, as one would expect, the longitudinal series runs somewhat higher because it encompasses life-cycle wage growth. But second, the cyclical patterns for the longitudinal series and the series from repeated cross-sections are remarkably similar. Although composition bias repeatedly has been found to be an important issue for measuring wage cyclicality in the United States, it appears to matter much less for Great Britain. Thus, we continue to find that real wage growth in Great Britain hardly slowed at all in the early 1980s, slowed more in the early 1990s, and went negative in the Great Recession.

We already have noted that this pattern cannot be explained by changes in the inflationary environment, which go the "wrong" way. So what does account for the increasing procyclicality of British real wages? One possibility - broached, for example, by Blundell, Crawford, and Jin (2013) - is that declining unionization has led to more flexible wages. Setting aside the puzzle of why the same trend has not led to greater wage flexibility in the United States as well, we can pursue the British evidence on this idea by redoing Figure 9 disaggregated by union status. Figure 10 shows mean year-to-year change in log real wages by gender separately for those who were in jobs covered by union agreements in both years and those who were in

\footnotetext{
${ }^{14}$ As in our longitudinal analysis for the United States, we also have tried estimating regressions with controls for a polynomial in age, but the variation over time in the estimated year effects is virtually identical to that for the unadjusted means shown in Table 8.
} 
non-union jobs in both years. The plots for union and non-union workers are strikingly similar to each other, and to the blue aggregate plots in Figure 9. Thus, although declining unionization could be part of the story, it cannot be nearly all of it. Even after controlling for union status, the procyclicality of real wages remains much stronger in the Great Recession than in earlier recessions.

\section{B. Nominal wages}

The relative accuracy of the payroll-based NES wage data is especially valuable in the analysis of year-to-year changes in nominal wages. It will be instructive here to begin by reviewing two previous British studies of nominal wage rigidity. Smith (2000) used the 19911996 waves of the British Household Panel Study (BHPS) to retrace the steps of the U.S. literature described in our Section II. Whereas most U.S. researchers have attempted to restrict their samples to workers staying with the same employer, Smith further restricted to workers who reported staying in the same job with the same employer. If anything, one would expect that difference to lead to a higher frequency of zero nominal wage change. Her initial results turned out to be fairly similar to those from U.S. household surveys for the same period - she

found that 9 percent of stayers experienced zero nominal wage change from one year to the next, and that 23 percent experienced nominal wage reductions.

But then she exploited a remarkable feature of the BHPS data - respondents were told they could consult their pay slips when answering the wage questions, and the survey recorded who did so. When Smith restricted her sample to those who did check their pay slips in both years, the proportion with zero nominal wage change fell to 5.6 percent. As we mentioned in Section II, it is ex ante unclear in which direction reporting error would bias the estimation of the spike at zero nominal wage change. Purely classical measurement error would bias the estimation downward, but rounding error could go the other way. For example, a worker whose hourly wage was $\$ 19.80$ last year and is $\$ 20.30$ this year might round to $\$ 20$ in both years and get coded as experiencing zero change. Smith's results suggest that, on net, nominal wage change distributions from household surveys overestimate the proportion of stayers with zero nominal wage change. Unsurprisingly, she also found that, among the respondents who did check their pay slips, the proportion reporting nominal wage reductions was somewhat smaller. But it was still quite substantial, at almost 18 percent. In combination, Smith took these results 
as showing that nominal wages are considerably more flexible than economists had believed. To quote her striking summary, "Some of the results in this paper may seem difficult to believe - the quite common occurrence of nominal pay cuts, for example. It may well be that the difficulty in believing them stems not from the weight of contradictory evidence, but rather from conventional wisdom that has survived because of the previous lack of evidence either way."

Smith's study was following by Nickell and Quintini's (2003) study based on the NES data for 1975-1999. Like Smith, Nickell and Quintini focused on workers staying in the same job with the same employer. Nickell and Quintini began by comparing their 1991-1996 nominal wage change measures, based on employers' payroll-based reporting, to Smith's household survey measures for the respondents who consulted their pay slips. The results from the two sources line up quite closely with each other. More generally, over their full 1975-1999 sample period, Nickell and Quintini found that there was regularly a noticeable spike at zero nominal wage change, but that it was much smaller than usually found in household surveys. In most years, the proportion of stayers with zero nominal wage change was less than 3 percent, with the highest proportion being 7.1 percent in 1992-1993. And despite the presumed accuracy of the employers' wage reports, the proportion of stayers with nominal wage reductions from year to year was substantial, ranging from a low of 5 percent in 1979-1980 (when the inflation rate was about 20 percent) to a high of 22 percent in 1996-1997. Nickell and Quintini concluded, "Despite the substantial numbers of individuals whose nominal wages fall from one year to the next, we find that there is evidence of some rigidity at zero nominal wage change. While the effect is statistically significant, the macroeconomic impact of the distortion is very modest."

Our analysis of the NES data updates Nickell and Quintini's analysis to 2011. As in our U.S. analysis of nominal wages in Section II, we pool women and men between the ages of 16 and 64. Unlike in our U.S. analysis, we pool hourly and non-hourly workers, who are not distinguished in the NES data. Because our analysis of year-to-year nominal wage changes is restricted to workers staying in the same job with the same employer, our sample sizes become somewhat smaller than in our longitudinal analysis of real wages in the NES. With women and men combined, our sample size starts at almost 60,000 for 1975-1976 and rises to over 100,000 by $2010-2011$.

Figure 11 presents histograms of job stayers' year-to-year nominal wage growth for each pair of years from 1975-1976 to 2010-2011. The histograms are laid out similarly to the U.S. 
ones in Figures 5 and 6, except that Figure 11 combines hourly and non-hourly workers. Because the spikes at zero are less prominent in the British data, we highlight them in red. We also insert a thin green spike at the inflation rate (the April-to-April change in the log of the RPIX) to mark the nominal wage growth corresponding to zero real wage growth. Table 9 lists some important summary statistics from the histograms.

Five patterns stand out in the histograms and table. First, like Nickell and Quintini, we find relatively small spikes at zero nominal wage change, ranging from a low of 0.4 percent in 1979-1980 to a high of 7.4 percent in 2009-2010. In most years, the spike is less than 3 percent. That the zero spikes are so much smaller in the British payroll-based data than in the U.S. household survey data raises the question of whether the larger U.S. spikes might be in considerable part an artifact of rounding error. We doubt that question can be answered convincingly until and unless payroll-based longitudinal hourly wage data become available for the United States.

Second, we replicate and update the finding of substantial proportions of British job stayers experiencing negative nominal wage changes. Our estimates range from a low of 5 percent in 1979-1980 to a high of 24 percent in 2009-2010. From 1993-1994 on (when the inflation rate typically has been about 3 percent), the proportion experiencing nominal wage cuts regularly has run in the neighborhood of 20 percent. Like the Smith and Nickell-Quintini studies before us, we are struck by the wage flexibility indicated in the frequency of nominal wage cuts as well as the infrequency of nominal wage freezes. Some U.S. writers, such as Altonji and Devereux (1999), have conjectured that the substantial fraction of U.S. job stayers reporting nominal wage reductions is an artifact of response error in household surveys. The payroll-based British data, however, also show many nominal wage cuts. This again underscores the need for payroll-based U.S. data. ${ }^{15}$

\footnotetext{
${ }^{15}$ In the meantime, anecdotal U.S. evidence is of some interest. Bewley's (1999) account of his interviews of employers during the recession of the early 1990s famously emphasizes employers' aversion to cutting nominal wages, but Sections 11.1 and 12.1 of the book document some instances of nominal wage reductions. Blinder and Choi's (1990) account of their smaller survey of employers includes this finding: "One surprising fact that was turned up is that money wage cuts are more common than we had imagined. Even though our interviews came at a time and place of extremely tight labor markets (unemployment rates were below 4 percent in many localities), a sizeable minority of firms had actually reduced wages to at least some employees in the recent past. Specifically, five of the 19 firms (26 percent) had recently cut money wages; while four others ( 21 percent) had reduced fringe benefits, mostly in minor ways.... Unless our small sample is unrepresentative in some important respect, money wage cuts are more prevalent than many economists (including ourselves) have supposed."
} 
Third, as in previous research for both Great Britain and the United States, the fractions of job stayers with zero and negative nominal wage changes vary over time with respect to inflation and business cycle conditions in the ways that one would expect. In the first few years of our British sample period, when inflation was particularly high, the fractions with zero and negative nominal wage changes were particularly low. In the last two years of the sample period, when the Great Recession was at its worst and inflation was moderate, the fractions with zero and negative nominal wage changes were higher than usual.

Fourth, some of the household-survey-based U.S. literature, such as Kahn (1997), has noted some evidence for dips in the distribution of nominal wage change in the bins immediately surrounding zero, and has interpreted those dips as possibly reflecting menu costs in wage setting. Such dips are not particularly apparent in our histograms from the British payroll-based data. And, as shown in Table 9, the percentages of job stayers with positive and negative log nominal wage changes no larger than 0.01 are non-trivial, reaching a combined share of more than 11 percent in the last two years of our sample period. This leads us to wonder whether rounding error in U.S. household surveys has not only exaggerated the spike at zero nominal wage change, but has done so by reducing the reporting of small non-zero nominal wage changes, thus creating the appearance of dips around zero in the histograms. Once again, settling that question will require access to payroll-based longitudinal hourly wage data for the United States.

Relatedly, our fifth observation is that the histograms for the last two years show a rise in the prevalence of nominal wage increases below the rate of inflation. This indicates that the reduction in British real wages during the Great Recession has arisen not only from increasing prevalence of nominal wage freezes and reductions, but also from increasing prevalence of nominal wage raises too small to keep up with inflation. ${ }^{16}$

\footnotetext{
${ }^{16}$ Following an excellent suggestion from David Green, we have checked what happens if we redo our British histograms with weekly instead of hourly earnings. The patterns are mostly the same. The percentage with nominal wage reductions is very similar. The percentage with zero nominal change goes up somewhat, but is still strikingly small compared to the U.S. estimates based on household surveys. In most years, it is less than 4 percent. The increase in the zero spike from using weekly instead of hourly earnings is about equal to the reduction in the percentage with positive or negative log changes no greater than 0.01. As a result, the percentage with log changes between 0.01 and -0.01 is about the same with the weekly vs. hourly wage measures.
} 


\section{Summary and Discussion}

Our analyses of both U.S. and British data replicate and update the finding of previous microdata-based studies that, by and large, real wages are substantially procyclical. The degree of real wage cyclicality, however, varies over time and place. Our analysis of March Current Population Survey data for the United States suggests that real wages took large hits in the recessions of the early 1980s and 1990s, but that men's real wages were somewhat less affected in the Great Recession. Because of difficulty in separating cyclical effects from secular trends, the picture for U.S. women is less clear, but a tentative impression is that the Great Recession's impact on U.S. women's real wages was particularly adverse. Our analysis of New Earnings Survey data for Great Britain also finds differences across recessions, with practically an opposite pattern to that for U.S. men. In Great Britain, real wages were not much affected by the severe recession of the early 1980s, displayed slowed growth in the severe recession of the early 1990s, and were affected very negatively by the Great Recession. The between-country difference in the evolution of real wage cyclicality over our sample period is all the more striking given that both countries experienced reductions in inflation and unionization.

We also have used the CPS and NES data to replicate and update the literature that documents the distribution of job stayers' year-to-year nominal wage changes. Like previous studies of U.S. household surveys, our CPS analysis finds a substantial minority of stayers reporting the exact same nominal wage from one year to the next (seemingly indicating a degree of nominal wage rigidity), but also a substantial minority reporting nominal wage reductions (seemingly indicating a degree of wage flexibility). As previous writers have noted, both findings may be distorted by reporting error. This makes the presumably more accurate NES wage data, reported by employers from payroll records, of particularly high interest. These data show a much lower frequency of zero year-to-year nominal wage change, but they show a surprisingly high frequency of nominal wage reductions. Like the authors of previous British studies of nominal wage change, we are struck by the apparent flexibility of British wages. We also wonder whether the measured between-country difference in the prevalence of zero nominal wage change is real or merely an artifact of rounding error in U.S. household surveys.

At an early stage of our project, we suspected that the sluggish response of U.S. men's real wages to the Great Recession might reflect an interaction of downward nominal wage stickiness with an environment of very low inflation, and we wondered whether such wage 
stickiness might have played an important role in the large upsurge of U.S. unemployment. While there may be something to that story, it lines up poorly with many other empirical patterns. Why did the Great Recession appear to have a particularly large effect on U.S. women's real wages? Even if the CPS data on the prevalence of zero nominal wage change are accurate, why didn't the prevalence rise more precipitously during the Great Recession? As discussed in Section II, there are theoretical reasons to question whether wage stickiness has major "allocative" effects on quantities like employment and unemployment. And empirically, if it does, one would expect the Great Recession to have featured an extraordinarily large upsurge in layoffs. Layoffs did indeed surge upwards, but similarly to how they did in previous severe recessions, including the high-inflation environment of the early 1980s. The more distinctive aspect of the U.S. labor market's response to the Great Recession has been the extraordinary length of unemployment spells. But it is hard to see why downward nominal wage rigidity would be more constraining for the hiring of new workers from the unemployed than it is for the retention of incumbent workers. Finally, if downward nominal wage stickiness was important in the U.S. experience of the Great Recession, why was it so much less so in Great Britain?

Questions like these leave us keenly aware that the results in our paper raise more questions than they answer. Beyond those just named in connection with nominal wage rigidity, many broader puzzles remain. For example, why have British real wages become more procyclical over time, with wages rather than employment taking much of the Great Recession's brunt? Why has the same trend not appeared in the United States? Why has U.S. unemployment duration become so long? In particular, why have primary-sector employers been so reluctant to hire, and why have the unemployed been so slow to take secondary-sector jobs?

The Great Recession has served as a reminder of how deeply important and puzzling is the behavior of labor markets over the business cycle. We are pleased that the NBER project of which our study is a part has succeeded in drawing labor economists back into this research area. Given the many important but unanswered questions, we hope that both labor economists and macroeconomists will continue to pursue both theoretical and empirical approaches to understanding how and why labor markets behave as they do over recessions and expansions. 
Table 1. U.S. Men's Mean and Median Log Real Wages (2009 Dollars) by Year

\begin{tabular}{|c|c|c|c|c|c|c|c|}
\hline Year & $\begin{array}{l}\text { Unemploy- } \\
\text { ment Rate }\end{array}$ & $\begin{array}{c}\text { Mean } \\
\text { Log Real } \\
\text { Wage } \\
\text { (PCE) }\end{array}$ & $\begin{array}{c}\text { Mean } \\
\text { Log Real } \\
\text { Wage } \\
\text { (CPI-U- } \\
\text { RS) }\end{array}$ & $\begin{array}{l}\text { Standard } \\
\text { Error for } \\
\text { Means }\end{array}$ & $\begin{array}{l}\text { Median } \\
\text { Log Real } \\
\text { Wage } \\
\text { (PCE) }\end{array}$ & $\begin{array}{l}\text { Median } \\
\text { Log Real } \\
\text { Wage } \\
\text { (CPI-U- } \\
\text { RS) }\end{array}$ & $\begin{array}{l}\text { Standard } \\
\text { Error for } \\
\text { Medians }\end{array}$ \\
\hline 1979 & 5.8 & 2.933 & 2.995 & 0.004 & 2.991 & 3.053 & 0.003 \\
\hline 1980 & 7.1 & 2.908 & 2.968 & 0.004 & 2.984 & 3.043 & 0.005 \\
\hline 1981 & 7.6 & 2.908 & 2.962 & 0.004 & 2.975 & 3.029 & 0.003 \\
\hline 1982 & 9.7 & 2.901 & 2.950 & 0.004 & 2.972 & 3.021 & 0.001 \\
\hline 1983 & 9.6 & 2.889 & 2.938 & 0.004 & 2.935 & 2.984 & 0.008 \\
\hline 1984 & 7.5 & 2.891 & 2.937 & 0.004 & 2.960 & 3.006 & 0.008 \\
\hline 1985 & 7.2 & 2.903 & 2.947 & 0.004 & 2.963 & 3.008 & 0.006 \\
\hline 1986 & 7.0 & 2.914 & 2.965 & 0.004 & 2.977 & 3.028 & 0.002 \\
\hline 1987 & 6.2 & 2.907 & 2.960 & 0.004 & 2.977 & 3.030 & 0.008 \\
\hline 1988 & 5.5 & 2.906 & 2.962 & 0.004 & 2.974 & 3.030 & 0.008 \\
\hline 1989 & 5.3 & 2.897 & 2.953 & 0.004 & 2.943 & 2.999 & 0.001 \\
\hline 1990 & 5.6 & 2.875 & 2.927 & 0.004 & 2.915 & 2.968 & 0.008 \\
\hline 1991 & 6.8 & 2.859 & 2.912 & 0.004 & 2.902 & 2.955 & 0.004 \\
\hline 1992 & 7.5 & 2.851 & 2.907 & 0.004 & 2.907 & 2.964 & 0.006 \\
\hline 1993 & 6.9 & 2.841 & 2.895 & 0.004 & 2.889 & 2.943 & 0.003 \\
\hline 1994 & 6.1 & 2.861 & 2.914 & 0.004 & 2.905 & 2.958 & 0.002 \\
\hline 1995 & 5.6 & 2.864 & 2.915 & 0.005 & 2.892 & 2.943 & 0.008 \\
\hline 1996 & 5.4 & 2.884 & 2.930 & 0.004 & 2.918 & 2.964 & 0.010 \\
\hline 1997 & 4.9 & 2.916 & 2.959 & 0.004 & 2.924 & 2.967 & 0.008 \\
\hline 1998 & 4.5 & 2.946 & 2.985 & 0.004 & 2.968 & 3.007 & 0.000 \\
\hline 1999 & 4.2 & 2.979 & 3.014 & 0.004 & 2.992 & 3.027 & 0.006 \\
\hline 2000 & 4.0 & 3.007 & 3.033 & 0.005 & 3.017 & 3.043 & 0.002 \\
\hline 2001 & 4.7 & 3.017 & 3.035 & 0.004 & 3.003 & 3.021 & 0.007 \\
\hline 2002 & 5.8 & 3.017 & 3.032 & 0.004 & 3.012 & 3.027 & 0.002 \\
\hline 2003 & 6.0 & 3.019 & 3.032 & 0.004 & 3.021 & 3.033 & 0.006 \\
\hline 2004 & 5.5 & 3.002 & 3.014 & 0.004 & 3.018 & 3.030 & 0.007 \\
\hline 2005 & 5.1 & 3.001 & 3.009 & 0.004 & 3.005 & 3.012 & 0.008 \\
\hline 2006 & 4.6 & 3.007 & 3.010 & 0.004 & 3.016 & 3.018 & 0.000 \\
\hline 2007 & 4.6 & 3.007 & 3.008 & 0.004 & 2.989 & 2.990 & 0.001 \\
\hline 2008 & 5.8 & 2.999 & 2.995 & 0.004 & 2.982 & 2.977 & 0.010 \\
\hline 2009 & 9.3 & 3.007 & 3.007 & 0.004 & 3.005 & 3.005 & 0.004 \\
\hline 2010 & 9.6 & 2.993 & 2.995 & 0.004 & 2.986 & 2.989 & 0.004 \\
\hline 2011 & 8.9 & 2.989 & 2.984 & 0.004 & 2.990 & 2.986 & 0.006 \\
\hline
\end{tabular}

Notes: The standard errors for means are robust to heteroskedasticity. The standard errors for medians are bootstrap estimates. In two years, the latter estimates are absolute zero. The reason is that, because of a substantial mass point at the sample median, the estimated median came out the same in every one of the 1,000 bootstrap replications. 
Table 2. U.S. Men's Log Real Wages (PCE Deflator) in Severe Recessions

\begin{tabular}{|c|c|c|c|c|}
\hline Year & $\begin{array}{c}\text { Mean Relative to } \\
\text { Pre-Recession } \\
\text { Year }\end{array}$ & $\begin{array}{c}\text { Regression- } \\
\text { Adjusted Mean }\end{array}$ & $\begin{array}{c}\text { Median Relative } \\
\text { to Pre-Recession } \\
\text { Year }\end{array}$ & $\begin{array}{l}\text { Regression- } \\
\text { Adjusted Median }\end{array}$ \\
\hline 1979 & $\begin{array}{c}0 \\
\text { (normalized) }\end{array}$ & $\begin{array}{c}0 \\
\text { (normalized) }\end{array}$ & $\begin{array}{c}0 \\
\text { (normalized) }\end{array}$ & $\begin{array}{c}0 \\
\text { (normalized) }\end{array}$ \\
\hline 1980 & $\begin{array}{l}-0.024 \\
(0.005)\end{array}$ & $\begin{array}{l}-0.025 \\
(0.005)\end{array}$ & $\begin{array}{l}-0.007 \\
(0.006)\end{array}$ & $\begin{array}{l}-0.020 \\
(0.005)\end{array}$ \\
\hline 1981 & $\begin{array}{l}-0.024 \\
(0.005)\end{array}$ & $\begin{array}{l}-0.030 \\
(0.005)\end{array}$ & $\begin{array}{l}-0.016 \\
(0.004)\end{array}$ & $\begin{array}{l}-0.030 \\
(0.005)\end{array}$ \\
\hline 1982 & $\begin{array}{l}-0.031 \\
(0.005)\end{array}$ & $\begin{array}{l}-0.043 \\
(0.005)\end{array}$ & $\begin{array}{l}-0.018 \\
(0.003)\end{array}$ & $\begin{array}{l}-0.043 \\
(0.006)\end{array}$ \\
\hline 1983 & $\begin{array}{l}-0.044 \\
(0.005) \\
\end{array}$ & $\begin{array}{l}-0.059 \\
(0.005) \\
\end{array}$ & $\begin{array}{l}-0.056 \\
(0.008) \\
\end{array}$ & $\begin{array}{l}-0.057 \\
(0.006) \\
\end{array}$ \\
\hline 2006 & $\begin{array}{c}0 \\
\text { (normalized) }\end{array}$ & $\begin{array}{c}0 \\
\text { (normalized) }\end{array}$ & $\begin{array}{c}0 \\
\text { (normalized) }\end{array}$ & $\begin{array}{c}0 \\
\text { (normalized) }\end{array}$ \\
\hline 2007 & $\begin{array}{c}0.000 \\
(0.005)\end{array}$ & $\begin{array}{l}-0.004 \\
(0.005)\end{array}$ & $\begin{array}{l}-0.027 \\
(0.001)\end{array}$ & $\begin{array}{c}0.001 \\
(0.005)\end{array}$ \\
\hline 2008 & $\begin{array}{l}-0.008 \\
(0.005)\end{array}$ & $\begin{array}{l}-0.011 \\
(0.005)\end{array}$ & $\begin{array}{l}-0.034 \\
(0.010)\end{array}$ & $\begin{array}{l}-0.007 \\
(0.005)\end{array}$ \\
\hline 2009 & $\begin{array}{c}0.000 \\
(0.005)\end{array}$ & $\begin{array}{l}-0.006 \\
(0.005)\end{array}$ & $\begin{array}{l}-0.011 \\
(0.004)\end{array}$ & $\begin{array}{l}-0.003 \\
(0.005)\end{array}$ \\
\hline 2010 & $\begin{array}{l}-0.014 \\
(0.005)\end{array}$ & $\begin{array}{l}-0.027 \\
(0.005)\end{array}$ & $\begin{array}{l}-0.030 \\
(0.004)\end{array}$ & $\begin{array}{l}-0.023 \\
(0.005)\end{array}$ \\
\hline 2011 & $\begin{array}{l}-0.018 \\
(0.005)\end{array}$ & $\begin{array}{l}-0.032 \\
(0.005)\end{array}$ & $\begin{array}{l}-0.026 \\
(0.006)\end{array}$ & $\begin{array}{l}-0.034 \\
(0.005)\end{array}$ \\
\hline
\end{tabular}

Notes: The numbers in parentheses are standard errors. The standard errors for means are robust to heteroskedasticity. The standard errors for medians are bootstrap estimates. 
Table 3. Mean Year-to-Year Changes in Log Real Wages (PCE Deflator) by Gender from Longitudinally Matched CPS Data

\begin{tabular}{|c|c|c|c|c|}
\hline Year & $\begin{array}{c}\text { Men's Mean } \\
\text { Log Real Wage } \\
\text { Change }\end{array}$ & Standard Error & $\begin{array}{c}\text { Women's Mean } \\
\text { Log Real Wage } \\
\text { Change }\end{array}$ & Standard Error \\
\hline 1979-1980 & -0.012 & 0.004 & 0.017 & 0.006 \\
\hline 1980-1981 & 0.010 & 0.005 & 0.018 & 0.006 \\
\hline 1981-1982 & 0.004 & 0.005 & 0.032 & 0.006 \\
\hline 1982-1983 & 0.003 & 0.005 & 0.026 & 0.006 \\
\hline 1983-1984 & -- & -- & -- & -- \\
\hline 1984-1985 & -- & -- & -- & -- \\
\hline $1985-1986$ & 0.040 & 0.005 & 0.031 & 0.006 \\
\hline 1986-1987 & 0.025 & 0.005 & 0.039 & 0.006 \\
\hline 1987-1988 & 0.032 & 0.006 & 0.015 & 0.007 \\
\hline 1988-1989 & 0.022 & 0.006 & 0.015 & 0.006 \\
\hline 1989-1990 & 0.004 & 0.006 & 0.008 & 0.006 \\
\hline 1990-1991 & 0.001 & 0.005 & 0.025 & 0.006 \\
\hline 1991-1992 & -0.001 & 0.006 & 0.012 & 0.007 \\
\hline 1992-1993 & 0.006 & 0.007 & 0.014 & 0.007 \\
\hline 1993-1994 & 0.010 & 0.007 & 0.028 & 0.008 \\
\hline 1994-1995 & -- & -- & -- & -- \\
\hline 1995-1996 & 0.025 & 0.007 & 0.047 & 0.007 \\
\hline 1996-1997 & 0.039 & 0.007 & 0.047 & 0.007 \\
\hline 1997-1998 & 0.046 & 0.007 & 0.059 & 0.007 \\
\hline 1998-1999 & 0.048 & 0.007 & 0.039 & 0.007 \\
\hline 1999-2000 & 0.049 & 0.007 & 0.043 & 0.007 \\
\hline $2000-2001$ & 0.035 & 0.007 & 0.039 & 0.007 \\
\hline $2001-2002$ & 0.023 & 0.007 & 0.038 & 0.007 \\
\hline $2002-2003$ & 0.027 & 0.007 & 0.018 & 0.007 \\
\hline 2003-2004 & 0.012 & 0.008 & 0.014 & 0.007 \\
\hline 2004-2005 & 0.007 & 0.007 & 0.021 & 0.007 \\
\hline $2005-2006$ & 0.025 & 0.007 & 0.016 & 0.007 \\
\hline $2006-2007$ & 0.010 & 0.007 & 0.024 & 0.007 \\
\hline $2007-2008$ & 0.006 & 0.007 & 0.002 & 0.007 \\
\hline $2008-2009$ & 0.022 & 0.007 & 0.040 & 0.007 \\
\hline $2009-2010$ & -0.003 & 0.007 & 0.009 & 0.007 \\
\hline $2010-2011$ & 0.016 & 0.007 & 0.009 & 0.007 \\
\hline
\end{tabular}

Notes: The standard errors are robust to heteroskedasticity. As explained in the text, data for 1983-1984, 1984-1985, and 1994-1995 could not be matched longitudinally because of the absence of residential information in 1985, and because of changes in household identifiers in 1983-1984 and 1994-1995. 
Table 4. U.S. Women's Mean and Median Log Real Wages (2009 Dollars) by Year

\begin{tabular}{|c|c|c|c|c|c|c|c|}
\hline Year & $\begin{array}{l}\text { Unemploy- } \\
\text { ment Rate }\end{array}$ & $\begin{array}{c}\text { Mean } \\
\text { Log Real } \\
\text { Wage } \\
\text { (PCE) }\end{array}$ & $\begin{array}{c}\text { Mean } \\
\text { Log Real } \\
\text { Wage } \\
\text { (CPI-U- } \\
\text { RS) }\end{array}$ & $\begin{array}{c}\text { Standard } \\
\text { Error for } \\
\text { Means }\end{array}$ & $\begin{array}{l}\text { Median } \\
\text { Log Real } \\
\text { Wage } \\
\text { (PCE) }\end{array}$ & $\begin{array}{c}\text { Median } \\
\text { Log Real } \\
\text { Wage } \\
\text { (CPI-U- } \\
\text { RS) }\end{array}$ & $\begin{array}{l}\text { Standard } \\
\text { Error for } \\
\text { Medians }\end{array}$ \\
\hline 1979 & 5.8 & 2.408 & 2.471 & 0.004 & 2.452 & 2.514 & 0.006 \\
\hline 1980 & 7.1 & 2.405 & 2.464 & 0.004 & 2.440 & 2.499 & 0.006 \\
\hline 1981 & 7.6 & 2.407 & 2.461 & 0.004 & 2.438 & 2.492 & 0.007 \\
\hline 1982 & 9.7 & 2.429 & 2.478 & 0.004 & 2.462 & 2.511 & 0.000 \\
\hline 1983 & 9.6 & 2.435 & 2.484 & 0.004 & 2.484 & 2.533 & 0.008 \\
\hline 1984 & 7.5 & 2.446 & 2.493 & 0.004 & 2.486 & 2.532 & 0.006 \\
\hline 1985 & 7.2 & 2.463 & 2.508 & 0.004 & 2.504 & 2.549 & 0.006 \\
\hline 1986 & 7.0 & 2.482 & 2.533 & 0.004 & 2.529 & 2.580 & 0.008 \\
\hline 1987 & 6.2 & 2.498 & 2.551 & 0.004 & 2.547 & 2.600 & 0.007 \\
\hline 1988 & 5.5 & 2.498 & 2.553 & 0.005 & 2.540 & 2.595 & 0.002 \\
\hline 1989 & 5.3 & 2.516 & 2.572 & 0.004 & 2.558 & 2.614 & 0.003 \\
\hline 1990 & 5.6 & 2.522 & 2.574 & 0.004 & 2.570 & 2.622 & 0.003 \\
\hline 1991 & 6.8 & 2.527 & 2.579 & 0.004 & 2.568 & 2.620 & 0.007 \\
\hline 1992 & 7.5 & 2.540 & 2.597 & 0.004 & 2.596 & 2.652 & 0.009 \\
\hline 1993 & 6.9 & 2.540 & 2.594 & 0.004 & 2.589 & 2.643 & 0.000 \\
\hline 1994 & 6.1 & 2.557 & 2.610 & 0.004 & 2.585 & 2.638 & 0.011 \\
\hline 1995 & 5.6 & 2.560 & 2.610 & 0.005 & 2.586 & 2.637 & 0.004 \\
\hline 1996 & 5.4 & 2.589 & 2.635 & 0.004 & 2.617 & 2.664 & 0.006 \\
\hline 1997 & 4.9 & 2.614 & 2.657 & 0.004 & 2.642 & 2.685 & 0.006 \\
\hline 1998 & 4.5 & 2.655 & 2.694 & 0.004 & 2.680 & 2.719 & 0.000 \\
\hline 1999 & 4.2 & 2.670 & 2.705 & 0.004 & 2.705 & 2.739 & 0.003 \\
\hline 2000 & 4.0 & 2.706 & 2.732 & 0.005 & 2.719 & 2.745 & 0.000 \\
\hline 2001 & 4.7 & 2.737 & 2.754 & 0.004 & 2.749 & 2.766 & 0.008 \\
\hline 2002 & 5.8 & 2.754 & 2.769 & 0.004 & 2.767 & 2.782 & 0.007 \\
\hline 2003 & 6.0 & 2.764 & 2.776 & 0.004 & 2.786 & 2.799 & 0.008 \\
\hline 2004 & 5.5 & 2.752 & 2.764 & 0.004 & 2.784 & 2.796 & 0.002 \\
\hline 2005 & 5.1 & 2.758 & 2.766 & 0.004 & 2.755 & 2.763 & 0.002 \\
\hline 2006 & 4.6 & 2.774 & 2.777 & 0.004 & 2.769 & 2.772 & 0.010 \\
\hline 2007 & 4.6 & 2.780 & 2.781 & 0.004 & 2.796 & 2.797 & 0.007 \\
\hline 2008 & 5.8 & 2.760 & 2.755 & 0.004 & 2.775 & 2.770 & 0.006 \\
\hline 2009 & 9.3 & 2.783 & 2.783 & 0.004 & 2.794 & 2.794 & 0.005 \\
\hline 2010 & 9.6 & 2.779 & 2.781 & 0.004 & 2.794 & 2.797 & 0.006 \\
\hline 2011 & 8.9 & 2.772 & 2.768 & 0.004 & 2.780 & 2.776 & 0.008 \\
\hline
\end{tabular}

Notes: The standard errors for means are robust to heteroskedasticity. The standard errors for medians are bootstrap estimates. In four years, the latter estimates are absolute zero. The reason is that, because of a substantial mass point at the sample median, the estimated median came out the same in every one of the 1,000 bootstrap replications. 
Table 5. U.S. Women's Log Real Wages (PCE Deflator) in Severe Recessions

\begin{tabular}{|c|c|c|c|c|}
\hline Year & $\begin{array}{c}\text { Mean Relative to } \\
\text { Pre-Recession } \\
\text { Year }\end{array}$ & $\begin{array}{c}\text { Regression- } \\
\text { Adjusted Mean }\end{array}$ & $\begin{array}{c}\text { Median Relative } \\
\text { to Pre-Recession } \\
\text { Year }\end{array}$ & $\begin{array}{c}\text { Regression- } \\
\text { Adjusted Median }\end{array}$ \\
\hline 1979 & 0 & 0 & 0 & 0 \\
(normalized) & (normalized) & (normalized) & (normalized) \\
\hline 1980 & -0.003 & -0.006 & -0.012 & -0.012 \\
& $(0.006)$ & $(0.006)$ & $(0.009)$ & $(0.005)$ \\
\hline 1981 & -0.001 & -0.010 & -0.014 & -0.022 \\
& $(0.006)$ & $(0.006)$ & $(0.009)$ & $(0.005)$ \\
\hline 1982 & 0.021 & 0.002 & 0.010 & -0.006 \\
& $(0.006)$ & $(0.006)$ & $(0.006)$ & $(0.006)$ \\
\hline 1983 & 0.027 & 0.004 & 0.032 & 0.008 \\
& $(0.006)$ & $(0.006)$ & $(0.010)$ & $(0.006)$ \\
\hline & & & & 0 \\
& & & 0 & 0.003 \\
& 0 & 0 & $($ normalized) & $($ normalized) \\
\hline 2006 & $($ normalized) & $($ normalized) & 0.027 & 0.003 \\
& 0.006 & -0.003 & $(0.012)$ & $(0.005)$ \\
\hline 2007 & $(0.005)$ & $(0.005)$ & 0.006 & -0.012 \\
& -0.014 & -0.022 & $(0.011)$ & $(0.005)$ \\
\hline 2008 & $(0.005)$ & $(0.005)$ & 0.025 & 0.003 \\
& 0.009 & -0.003 & $(0.011)$ & $(0.005)$ \\
\hline 2009 & $(0.005)$ & $(0.005)$ & 0.026 & -0.012 \\
& 0.005 & -0.015 & $(0.011)$ & $(0.005)$ \\
\hline 2011 & $(0.005)$ & $(0.005)$ & 0.011 & -0.023 \\
& -0.002 & -0.025 & $(0.010)$ & $(0.005)$ \\
\hline & $(0.005)$ & $(0.005)$ & & \\
\hline & & & & \\
\hline
\end{tabular}

Notes: The numbers in parentheses are standard errors. The standard errors for means are robust to heteroskedasticity. The standard errors for medians are bootstrap estimates. 
Table 6. Nominal Wage Rigidity in the United States

\begin{tabular}{|c|c|c|c|c|c|c|}
\hline \multirow{2}{*}{ Years } & \multirow{2}{*}{$\begin{array}{c}\text { Annual } \\
\text { Unemploy- } \\
\text { ment Rate } \\
\text { in Year t-1 }\end{array}$} & \multirow{2}{*}{$\begin{array}{l}\text { Survey-to- } \\
\text { Survey } \\
\text { Change in } \\
\text { Log PCE } \\
\text { Deflator }\end{array}$} & \multicolumn{2}{|c|}{$\begin{array}{l}\text { Percentage of Hourly } \\
\text { Workers with: }\end{array}$} & \multicolumn{2}{|c|}{$\begin{array}{l}\text { Percentage of Non- } \\
\text { Hourly Workers with: }\end{array}$} \\
\hline & & & $\begin{array}{c}\text { Zero } \\
\text { Nominal } \\
\text { Wage } \\
\text { Change }\end{array}$ & $\begin{array}{l}\text { Negative } \\
\text { Nominal } \\
\text { Wage } \\
\text { Change }\end{array}$ & $\begin{array}{c}\text { Zero } \\
\text { Nominal } \\
\text { Wage } \\
\text { Change }\end{array}$ & $\begin{array}{c}\text { Negative } \\
\text { Nominal } \\
\text { Wage } \\
\text { Change }\end{array}$ \\
\hline 1980-1981 & 7.1 & 0.099 & 6.2 & 11.2 & 11.0 & 21.5 \\
\hline $1982-1983$ & 9.7 & 0.046 & 14.4 & 16.6 & 12.4 & 23.5 \\
\hline 1986-1987 & 7.0 & 0.023 & 15.2 & 17.9 & 11.8 & 27.9 \\
\hline 1990-1991 & 5.6 & 0.047 & 12.4 & 19.9 & 11.1 & 30.1 \\
\hline 1997-1998 & 4.9 & 0.009 & 14.6 & 17.7 & 9.3 & 26.8 \\
\hline $1999-2000$ & 4.2 & 0.025 & 14.7 & 15.9 & 8.9 & 26.0 \\
\hline $2001-2002$ & 4.7 & 0.007 & 16.2 & 14.2 & 11.9 & 26.5 \\
\hline $2003-2004$ & 6.0 & 0.021 & 17.6 & 19.5 & 12.9 & 30.2 \\
\hline $2005-2006$ & 5.1 & 0.032 & 17.6 & 17.0 & 12.0 & 26.6 \\
\hline $2007-2008$ & 4.6 & 0.035 & 17.7 & 18.7 & 9.4 & 37.1 \\
\hline $2009-2010$ & 9.3 & 0.024 & 19.3 & 23.4 & 14.9 & 33.7 \\
\hline 2011-2012 & 8.9 & 0.024 & 19.5 & 25.5 & 13.9 & 33.1 \\
\hline
\end{tabular}


Table 7. Mean Log Real Wages in Great Britain (2012 Pounds) by Gender and Year

\begin{tabular}{|c|c|c|c|c|c|}
\hline Year & $\begin{array}{l}\text { Unemployment } \\
\text { Rate }\end{array}$ & Men & $\begin{array}{c}\text { Estimated } \\
\text { Standard Error }\end{array}$ & Women & $\begin{array}{c}\text { Estimated } \\
\text { Standard Error }\end{array}$ \\
\hline 1975 & 4.2 & 2.270 & 0.001 & 1.873 & 0.002 \\
\hline 1976 & 5.4 & 2.275 & 0.001 & 1.904 & 0.002 \\
\hline 1977 & 5.5 & 2.204 & 0.001 & 1.843 & 0.002 \\
\hline 1978 & 5.6 & 2.240 & 0.001 & 1.860 & 0.002 \\
\hline 1979 & 5.3 & 2.282 & 0.001 & 1.888 & 0.002 \\
\hline 1980 & 6.1 & 2.294 & 0.001 & 1.910 & 0.002 \\
\hline 1981 & 9.4 & 2.317 & 0.002 & 1.937 & 0.002 \\
\hline 1982 & 10.5 & 2.328 & 0.002 & 1.936 & 0.002 \\
\hline 1983 & 11.3 & 2.363 & 0.002 & 1.981 & 0.002 \\
\hline 1984 & 11.9 & 2.384 & 0.002 & 2.002 & 0.002 \\
\hline 1985 & 11.4 & 2.396 & 0.002 & 2.021 & 0.002 \\
\hline 1986 & 11.3 & 2.435 & 0.002 & 2.060 & 0.002 \\
\hline 1987 & 10.9 & 2.471 & 0.002 & 2.093 & 0.002 \\
\hline 1988 & 8.9 & 2.506 & 0.002 & 2.139 & 0.002 \\
\hline 1989 & 7.3 & 2.536 & 0.002 & 2.184 & 0.002 \\
\hline 1990 & 6.9 & 2.551 & 0.002 & 2.200 & 0.002 \\
\hline 1991 & 8.5 & 2.577 & 0.002 & 2.244 & 0.002 \\
\hline 1992 & 9.8 & 2.583 & 0.002 & 2.261 & 0.002 \\
\hline 1993 & 10.5 & 2.592 & 0.002 & 2.276 & 0.002 \\
\hline 1994 & 9.7 & 2.586 & 0.002 & 2.277 & 0.002 \\
\hline 1995 & 8.8 & 2.587 & 0.002 & 2.287 & 0.002 \\
\hline 1996 & 8.3 & 2.594 & 0.002 & 2.293 & 0.002 \\
\hline 1997 & 7.2 & 2.609 & 0.002 & 2.313 & 0.002 \\
\hline 1998 & 6.3 & 2.619 & 0.002 & 2.328 & 0.002 \\
\hline 1999 & 6.1 & 2.637 & 0.002 & 2.359 & 0.002 \\
\hline 2000 & 5.6 & 2.651 & 0.002 & 2.374 & 0.002 \\
\hline 2001 & 4.9 & 2.688 & 0.002 & 2.409 & 0.002 \\
\hline 2002 & 5.2 & 2.712 & 0.002 & 2.430 & 0.002 \\
\hline 2003 & 5.0 & 2.709 & 0.002 & 2.450 & 0.002 \\
\hline 2004 & 4.8 & 2.711 & 0.002 & 2.463 & 0.002 \\
\hline 2005 & 4.8 & 2.731 & 0.002 & 2.493 & 0.002 \\
\hline 2006 & 5.4 & 2.741 & 0.002 & 2.507 & 0.002 \\
\hline 2007 & 5.4 & 2.749 & 0.002 & 2.510 & 0.002 \\
\hline 2008 & 5.2 & 2.743 & 0.002 & 2.508 & 0.002 \\
\hline 2009 & 7.6 & 2.747 & 0.002 & 2.532 & 0.002 \\
\hline 2010 & 7.9 & 2.693 & 0.002 & 2.491 & 0.002 \\
\hline 2011 & 7.8 & 2.640 & 0.002 & 2.450 & 0.002 \\
\hline
\end{tabular}

Note: The standard errors are robust to heteroskedasticity. 
Table 8. Mean Year-to Year Changes in Log Real Wages by Gender from Longitudinally Matched NES Data

\begin{tabular}{|c|c|c|c|c|c|}
\hline Year & $\begin{array}{l}\text { Unemploy- } \\
\text { ment Rate } \\
\text { (End of } \\
\text { Period) }\end{array}$ & $\begin{array}{l}\text { Men's Mean } \\
\text { Log Real Wage } \\
\text { Change }\end{array}$ & Standard Error & $\begin{array}{c}\text { Women's } \\
\text { Mean Log Real } \\
\text { Wage Change }\end{array}$ & Standard Error \\
\hline $1975-1976$ & 5.4 & 0.011 & 0.001 & 0.040 & 0.001 \\
\hline 1976-1977 & 5.5 & -0.067 & 0.001 & -0.046 & 0.001 \\
\hline $1977-1978$ & 5.6 & 0.025 & 0.001 & 0.013 & 0.001 \\
\hline 1978-1979 & 5.3 & 0.049 & 0.001 & 0.035 & 0.001 \\
\hline 1979-1980 & 6.1 & 0.029 & 0.001 & 0.033 & 0.001 \\
\hline 1980-1981 & 9.4 & 0.023 & 0.001 & 0.028 & 0.001 \\
\hline 1981-1982 & 10.5 & 0.014 & 0.001 & 0.003 & 0.001 \\
\hline 1982-1983 & 11.3 & 0.036 & 0.001 & 0.043 & 0.001 \\
\hline 1983-1984 & 11.9 & 0.027 & 0.001 & 0.019 & 0.001 \\
\hline 1984-1985 & 11.4 & 0.024 & 0.001 & 0.029 & 0.001 \\
\hline $1985-1986$ & 11.3 & 0.052 & 0.001 & 0.054 & 0.001 \\
\hline 1986-1987 & 10.9 & 0.047 & 0.001 & 0.051 & 0.001 \\
\hline $1987-1988$ & 8.9 & 0.054 & 0.001 & 0.060 & 0.001 \\
\hline 1988-1989 & 7.3 & 0.048 & 0.001 & 0.059 & 0.001 \\
\hline 1989-1990 & 6.9 & 0.032 & 0.001 & 0.041 & 0.001 \\
\hline 1990-1991 & 8.5 & 0.035 & 0.001 & 0.047 & 0.001 \\
\hline 1991-1992 & 9.8 & 0.017 & 0.001 & 0.029 & 0.001 \\
\hline 1992-1993 & 10.5 & 0.018 & 0.001 & 0.026 & 0.001 \\
\hline 1993-1994 & 9.7 & 0.009 & 0.001 & 0.016 & 0.001 \\
\hline 1994-1995 & 8.8 & 0.013 & 0.001 & 0.011 & 0.001 \\
\hline 1995-1996 & 8.3 & 0.021 & 0.001 & 0.018 & 0.001 \\
\hline 1996-1997 & 7.2 & 0.027 & 0.001 & 0.027 & 0.001 \\
\hline 1997-1998 & 6.3 & 0.030 & 0.001 & 0.023 & 0.001 \\
\hline 1998-1999 & 6.1 & 0.033 & 0.001 & 0.037 & 0.001 \\
\hline $1999-2000$ & 5.6 & 0.035 & 0.001 & 0.040 & 0.001 \\
\hline $2000-2001$ & 4.9 & 0.050 & 0.001 & 0.052 & 0.001 \\
\hline $2001-2002$ & 5.2 & 0.041 & 0.001 & 0.041 & 0.001 \\
\hline $2002-2003$ & 5.0 & 0.022 & 0.001 & 0.034 & 0.001 \\
\hline 2003-2004 & 4.8 & 0.026 & 0.001 & 0.032 & 0.001 \\
\hline $2004-2005$ & 4.8 & 0.046 & 0.001 & 0.050 & 0.001 \\
\hline $2005-2006$ & 5.4 & 0.032 & 0.001 & 0.031 & 0.001 \\
\hline $2006-2007$ & 5.4 & 0.023 & 0.001 & 0.021 & 0.001 \\
\hline $2007-2008$ & 5.2 & 0.016 & 0.001 & 0.012 & 0.001 \\
\hline $2008-2009$ & 7.6 & 0.028 & 0.001 & 0.039 & 0.001 \\
\hline $2009-2010$ & 7.9 & -0.026 & 0.001 & -0.018 & 0.001 \\
\hline $2010-2011$ & 7.8 & -0.030 & 0.001 & -0.028 & 0.001 \\
\hline
\end{tabular}

Note: The standard errors are robust to heteroskedasticity. 
Table 9. Nominal Wage Rigidity in Great Britain

\begin{tabular}{|c|c|c|c|c|c|c|}
\hline \multirow[b]{2}{*}{ Years } & \multirow{2}{*}{$\begin{array}{l}\text { Start-of- } \\
\text { Period } \\
\text { Unemploy- } \\
\text { ment Rate }\end{array}$} & \multirow{2}{*}{$\begin{array}{l}\text { April-to- } \\
\text { April } \\
\text { Change in } \\
\text { Log RPIX }\end{array}$} & \multicolumn{4}{|c|}{ Percentage of Log Nominal Wage Changes by Interval: } \\
\hline & & & Exactly 0 & {$[-0.01,0)$} & $(0,0.01]$ & Less than 0 \\
\hline $1975-1976$ & 4.2 & 0.175 & 0.6 & 0.4 & 0.4 & 5.2 \\
\hline 1976-1977 & 5.4 & 0.160 & 1.1 & 0.8 & 1.0 & 9.1 \\
\hline 1977-1978 & 5.5 & 0.083 & 1.7 & 0.9 & 1.1 & 8.9 \\
\hline 1978-1979 & 5.6 & 0.087 & 1.8 & 0.7 & 0.9 & 8.4 \\
\hline $1979-1980$ & 5.3 & 0.188 & 0.4 & 0.3 & 0.4 & 4.9 \\
\hline 1980-1981 & 6.1 & 0.117 & 2.0 & 0.7 & 0.8 & 8.6 \\
\hline 1981-1982 & 9.4 & 0.087 & 2.3 & 0.8 & 1.0 & 9.2 \\
\hline 1982-1983 & 10.5 & 0.048 & 1.8 & 0.9 & 1.2 & 10.5 \\
\hline 1983-1984 & 11.3 & 0.048 & 4.1 & 1.2 & 1.7 & 12.8 \\
\hline 1984-1985 & 11.9 & 0.052 & 1.4 & 1.0 & 1.3 & 11.9 \\
\hline 1985-1986 & 11.4 & 0.033 & 1.2 & 1.6 & 1.2 & 12.2 \\
\hline 1986-1987 & 11.3 & 0.035 & 2.1 & 1.2 & 1.3 & 12.2 \\
\hline 1987-1988 & 10.9 & 0.041 & 1.3 & 0.9 & 1.2 & 11.6 \\
\hline 1988-1989 & 8.9 & 0.057 & 1.8 & 1.0 & 1.1 & 11.0 \\
\hline 1989-1990 & 7.3 & 0.076 & 2.1 & 1.0 & 1.2 & 11.0 \\
\hline 1990-1991 & 6.9 & 0.066 & 2.3 & 0.9 & 1.0 & 11.4 \\
\hline 1991-1992 & 8.5 & 0.055 & 4.2 & 1.3 & 1.6 & 13.7 \\
\hline 1992-1993 & 9.8 & 0.029 & 6.0 & 1.8 & 2.8 & 16.7 \\
\hline 1993-1994 & 10.5 & 0.023 & 5.5 & 2.4 & 3.0 & 19.9 \\
\hline 1994-1995 & 9.7 & 0.026 & 4.9 & 1.9 & 2.6 & 20.9 \\
\hline $1995-1996$ & 8.8 & 0.029 & 1.3 & 1.8 & 4.4 & 19.9 \\
\hline 1996-1997 & 8.3 & 0.025 & 1.5 & 4.9 & 2.8 & 22.8 \\
\hline $1997-1998$ & 7.2 & 0.030 & 3.4 & 1.8 & 2.0 & 20.2 \\
\hline 1998-1999 & 6.3 & 0.024 & 3.8 & 1.6 & 2.0 & 18.1 \\
\hline 1999-2000 & 6.1 & 0.019 & 3.8 & 2.0 & 2.4 & 18.7 \\
\hline $2000-2001$ & 5.6 & 0.020 & 3.4 & 1.6 & 3.4 & 15.2 \\
\hline $2001-2002$ & 4.9 & 0.023 & 1.2 & 3.4 & 3.8 & 19.5 \\
\hline $2002-2003$ & 5.2 & 0.030 & 1.3 & 2.6 & 4.2 & 20.7 \\
\hline 2003-2004 & 5.0 & 0.020 & 0.9 & 4.7 & 4.4 & 23.2 \\
\hline 2004-2005 & 4.8 & 0.023 & 1.3 & 3.1 & 2.4 & 18.4 \\
\hline 2005-2006 & 4.8 & 0.024 & 1.9 & 3.3 & 3.8 & 21.4 \\
\hline $2006-2007$ & 5.4 & 0.035 & 1.7 & 3.8 & 4.2 & 20.5 \\
\hline $2007-2008$ & 5.4 & 0.039 & 2.7 & 2.6 & 3.0 & 18.4 \\
\hline $2008-2009$ & 5.2 & 0.017 & 4.5 & 3.3 & 3.4 & 19.4 \\
\hline 2009-2010 & 7.6 & 0.053 & 7.4 & 4.2 & 7.5 & 23.6 \\
\hline $2010-2011$ & 7.9 & 0.052 & 6.8 & 4.4 & 7.0 & 23.1 \\
\hline
\end{tabular}


Figure 1. U.S. Men's Mean Log Real Wages (PCE Deflator) over the Business Cycle

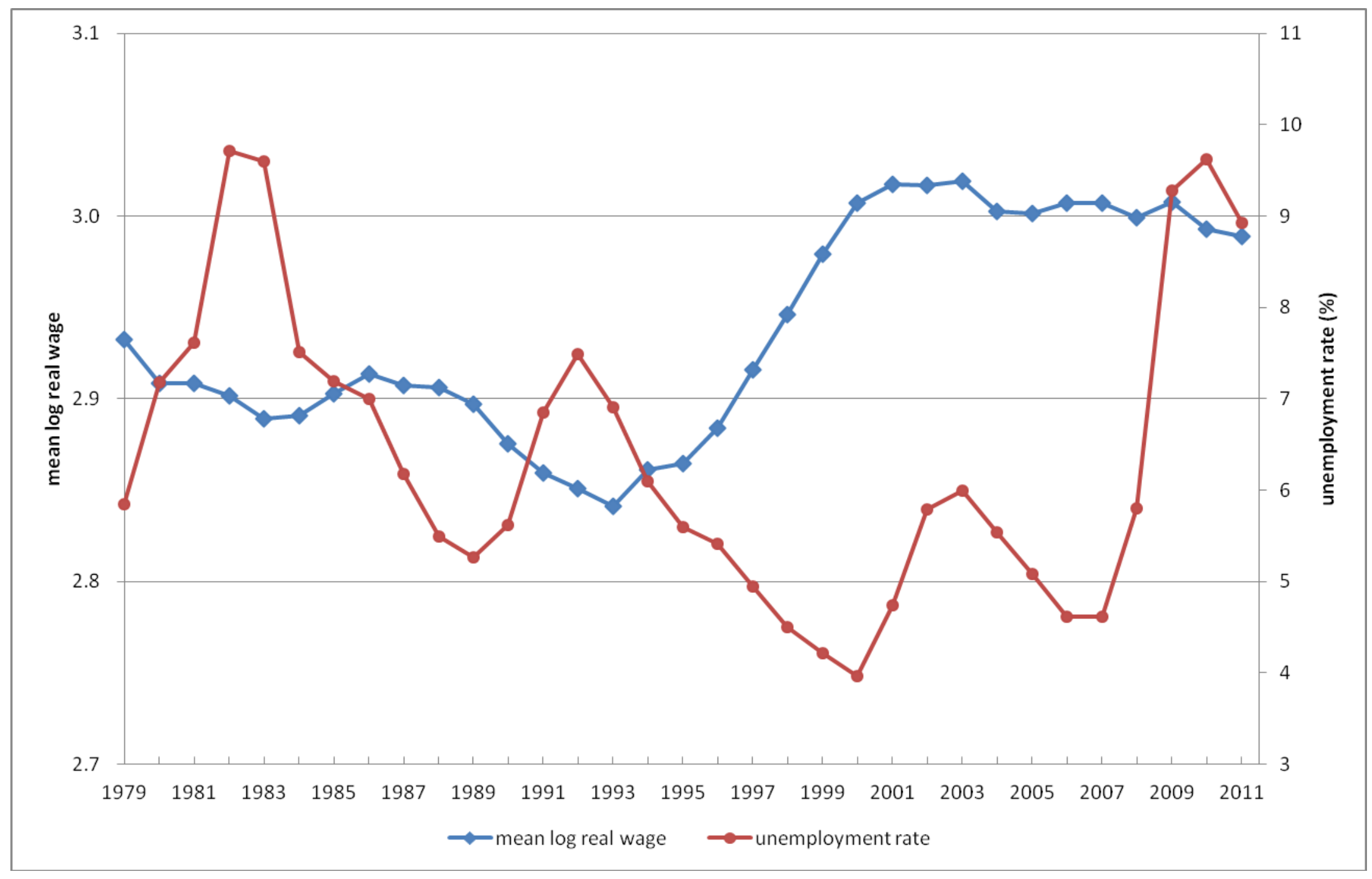


Figure 2. U.S. Women's Mean Log Real Wages (PCE Deflator) over the Business Cycle

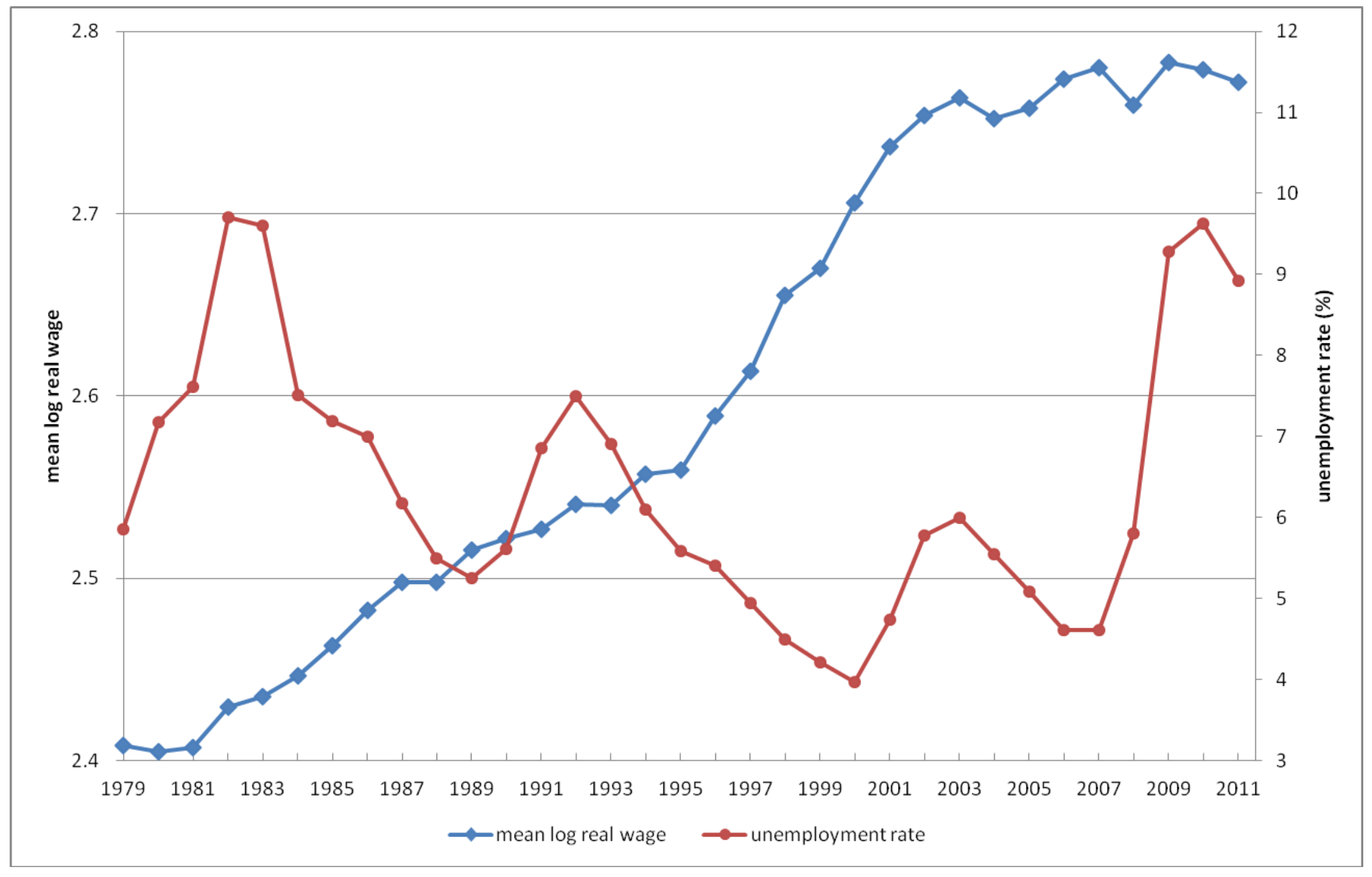


Figure 3. U.S. Men's Mean Log Real and Nominal Wages

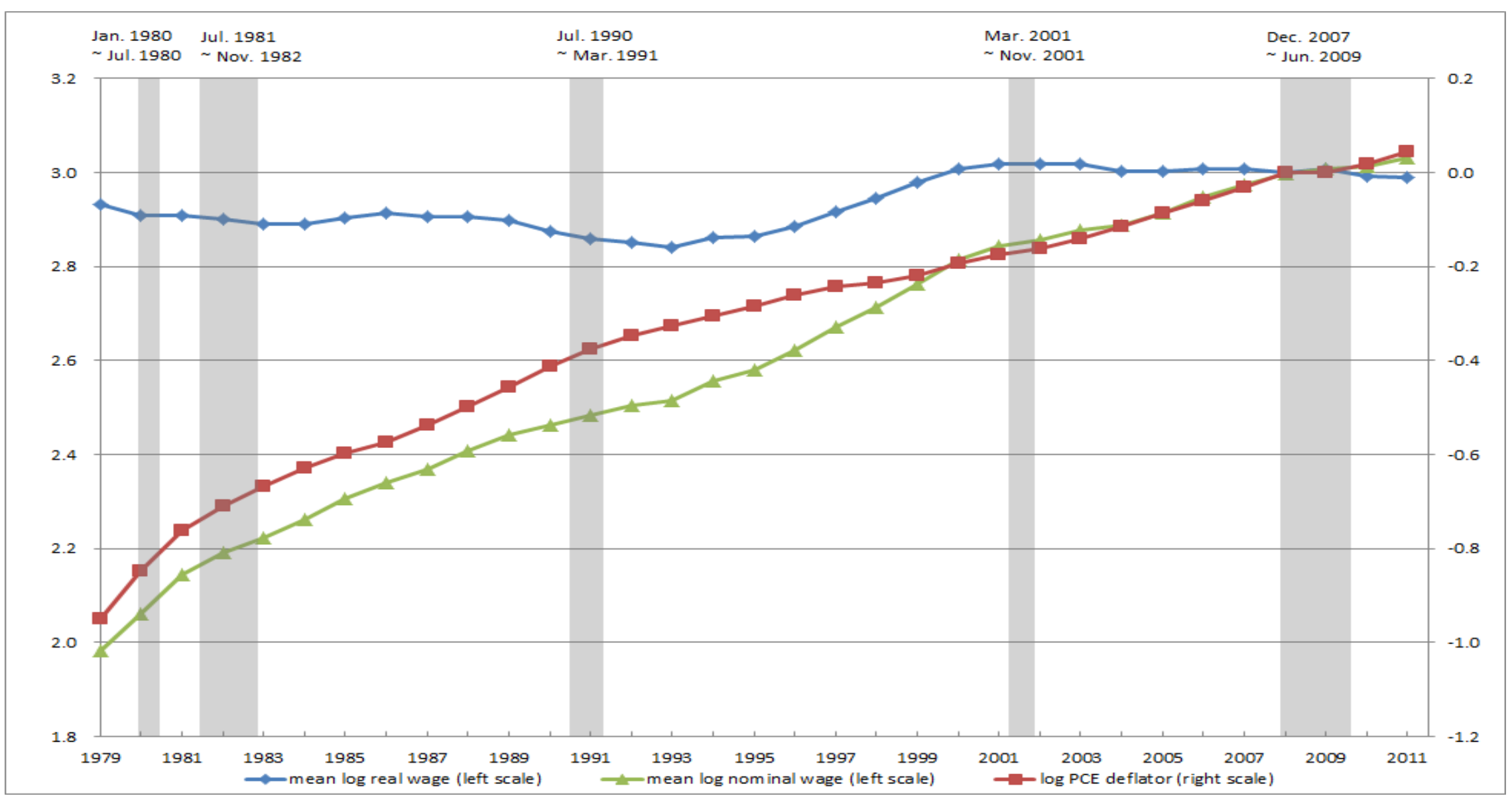


Figure 4. U.S. Women's Mean Log Real and Nominal Wages

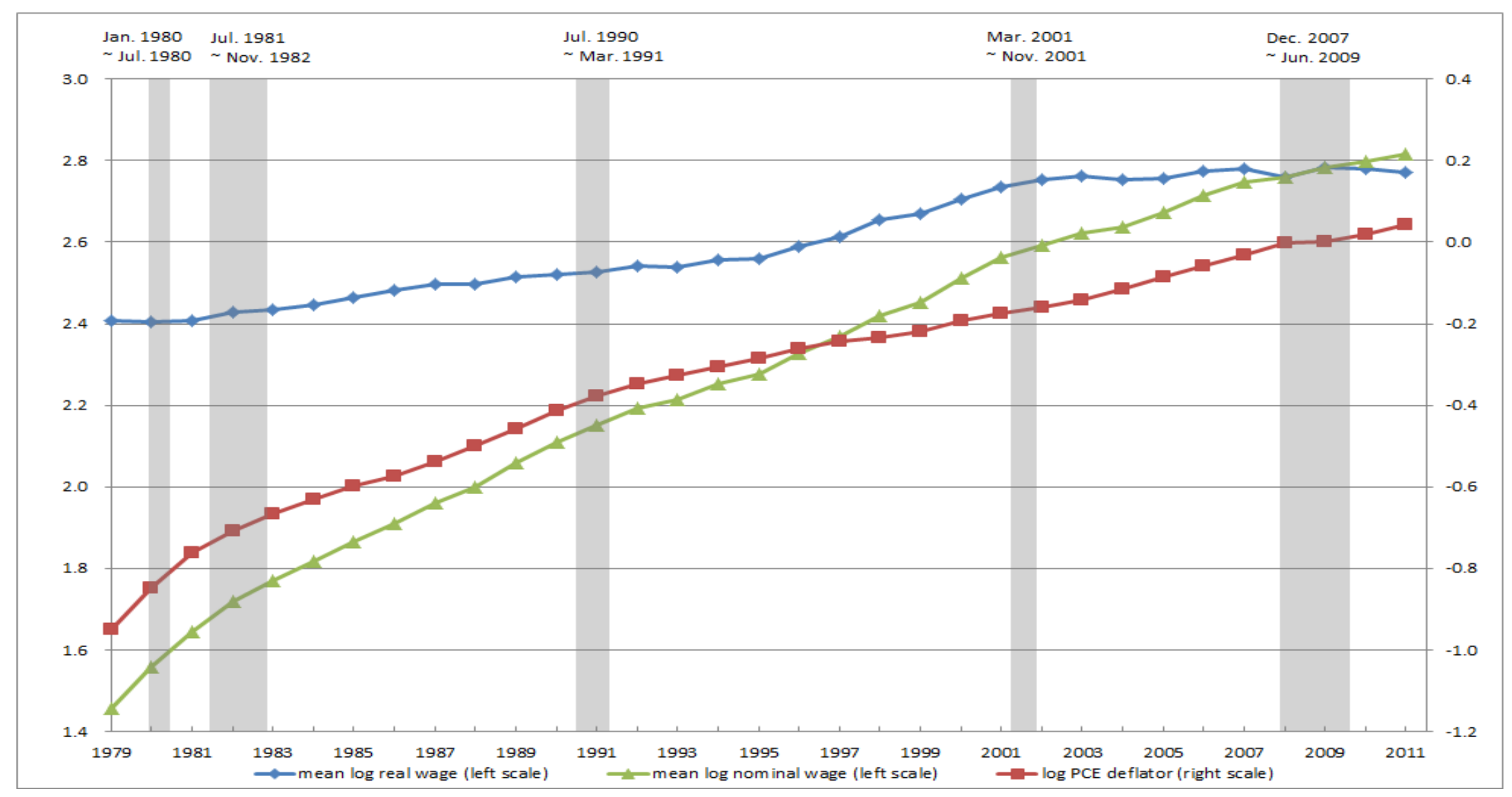


Figure 5. Distributions of Year-to-Year Change in Log Nominal Hourly Wages for U.S. Hourly Workers
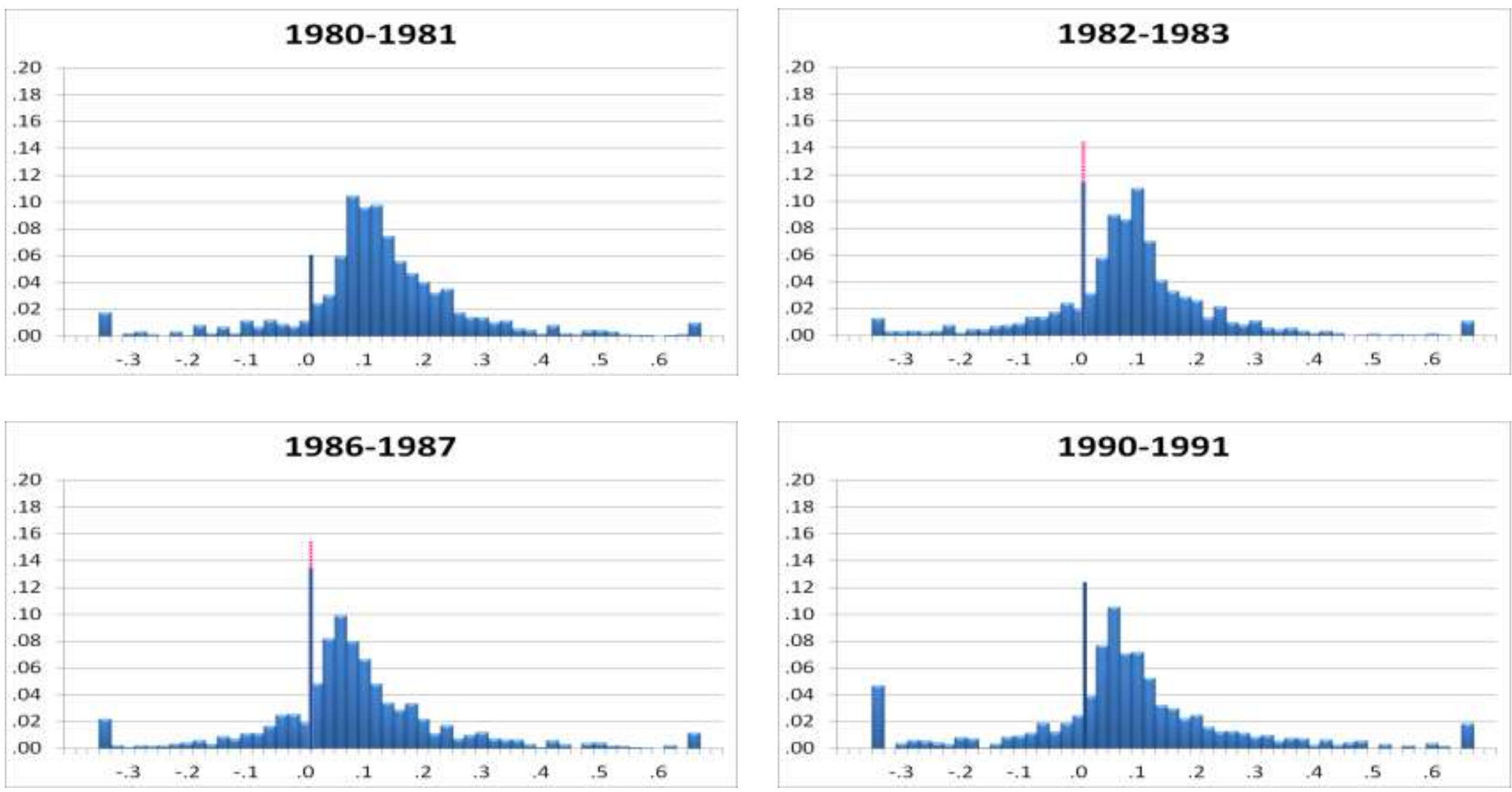
Figure 5 continued
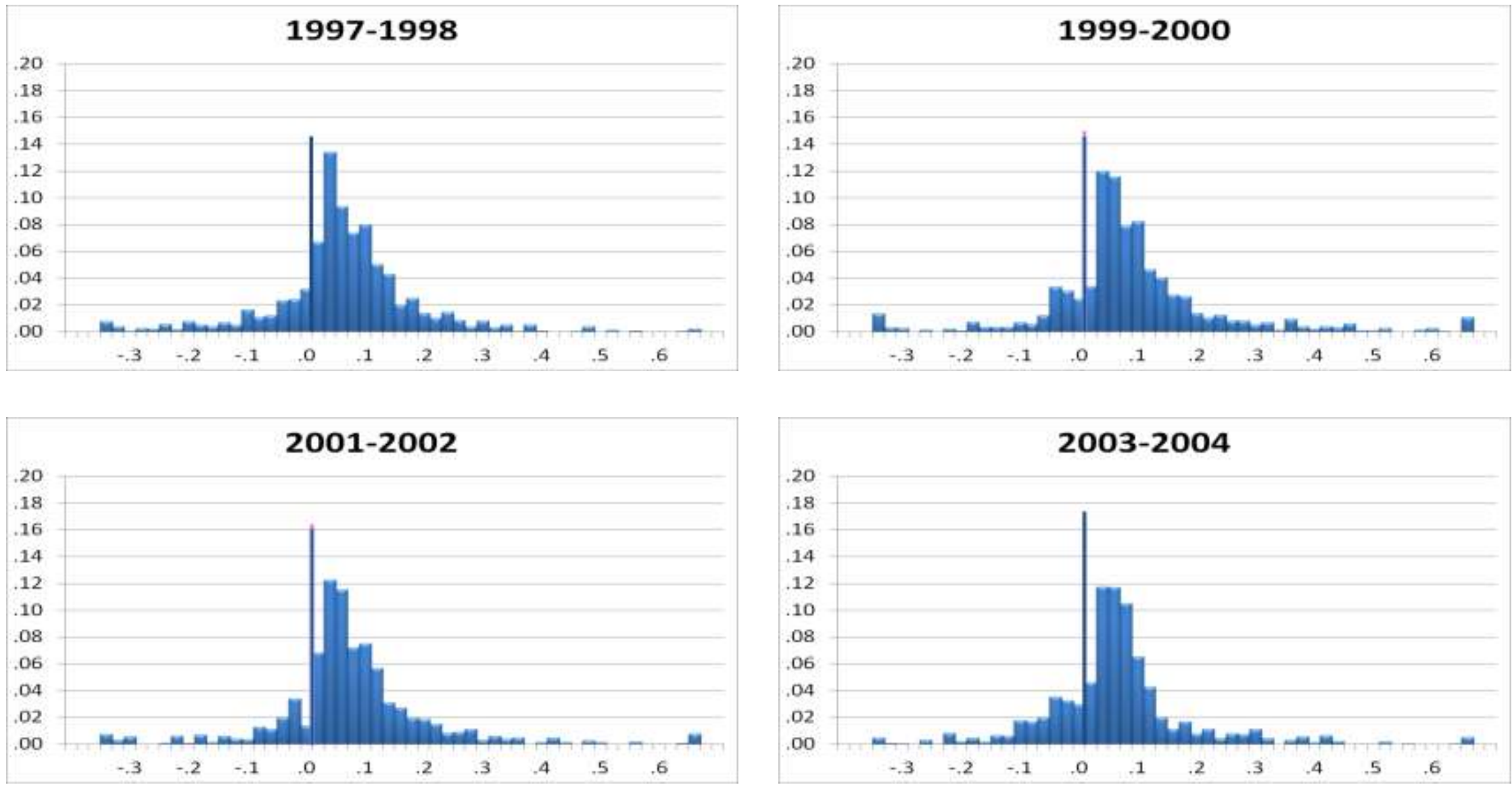
Figure 5 continued
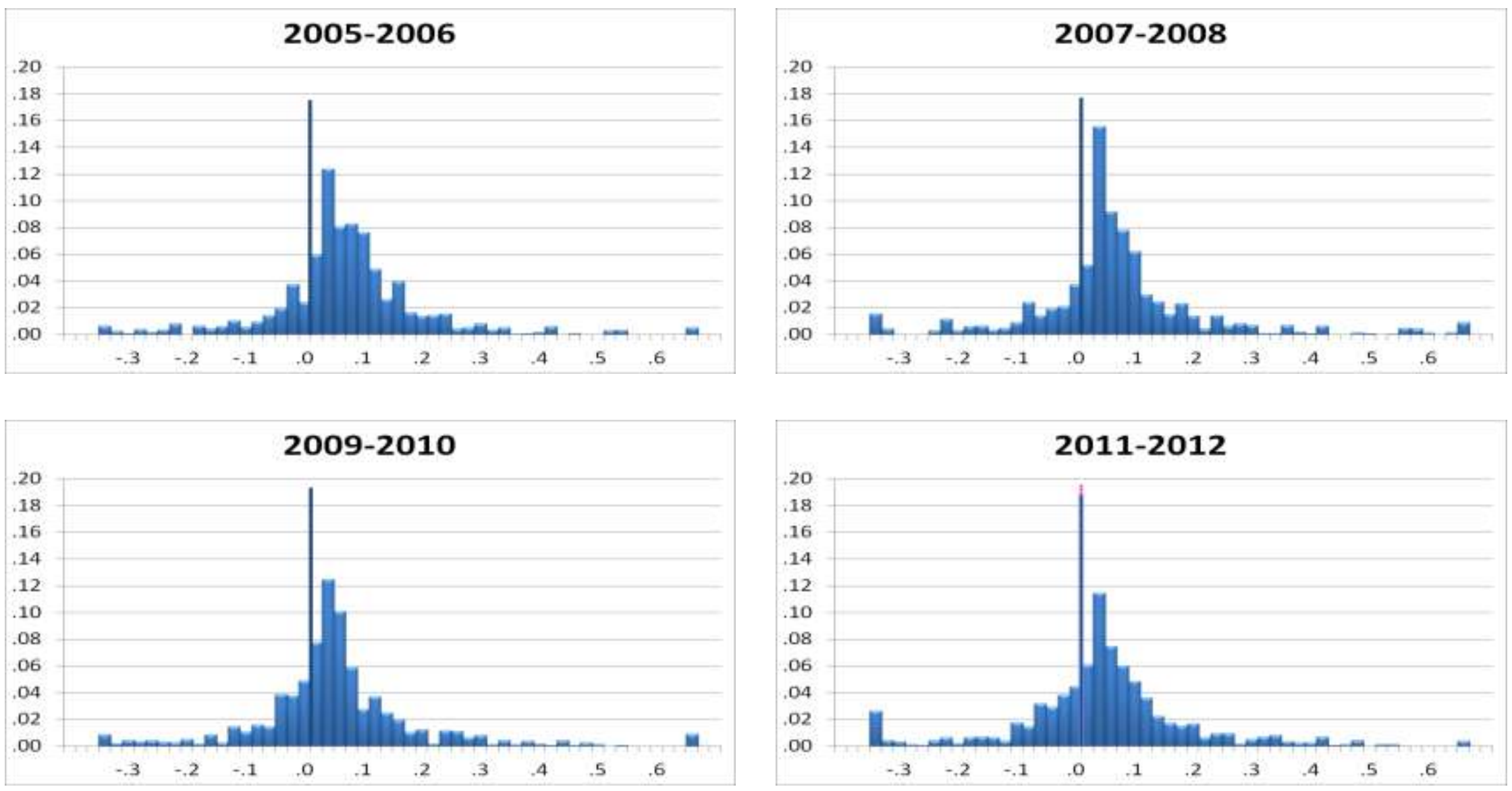
Figure 6. Distributions of Year-toYear Change in Log Nominal Weekly Earnings for U.S. Non-Hourly Workers
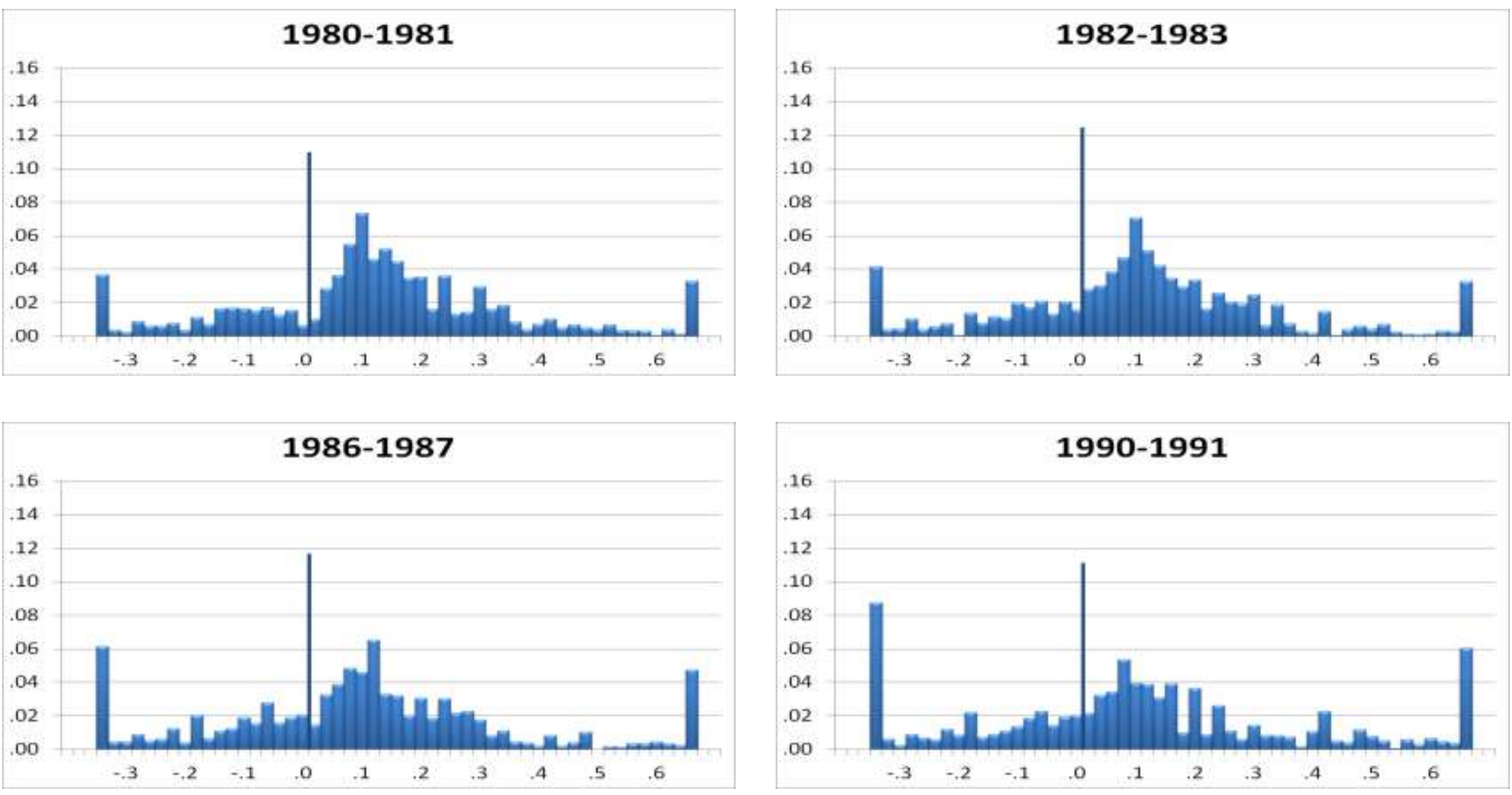
Figure 6 continued
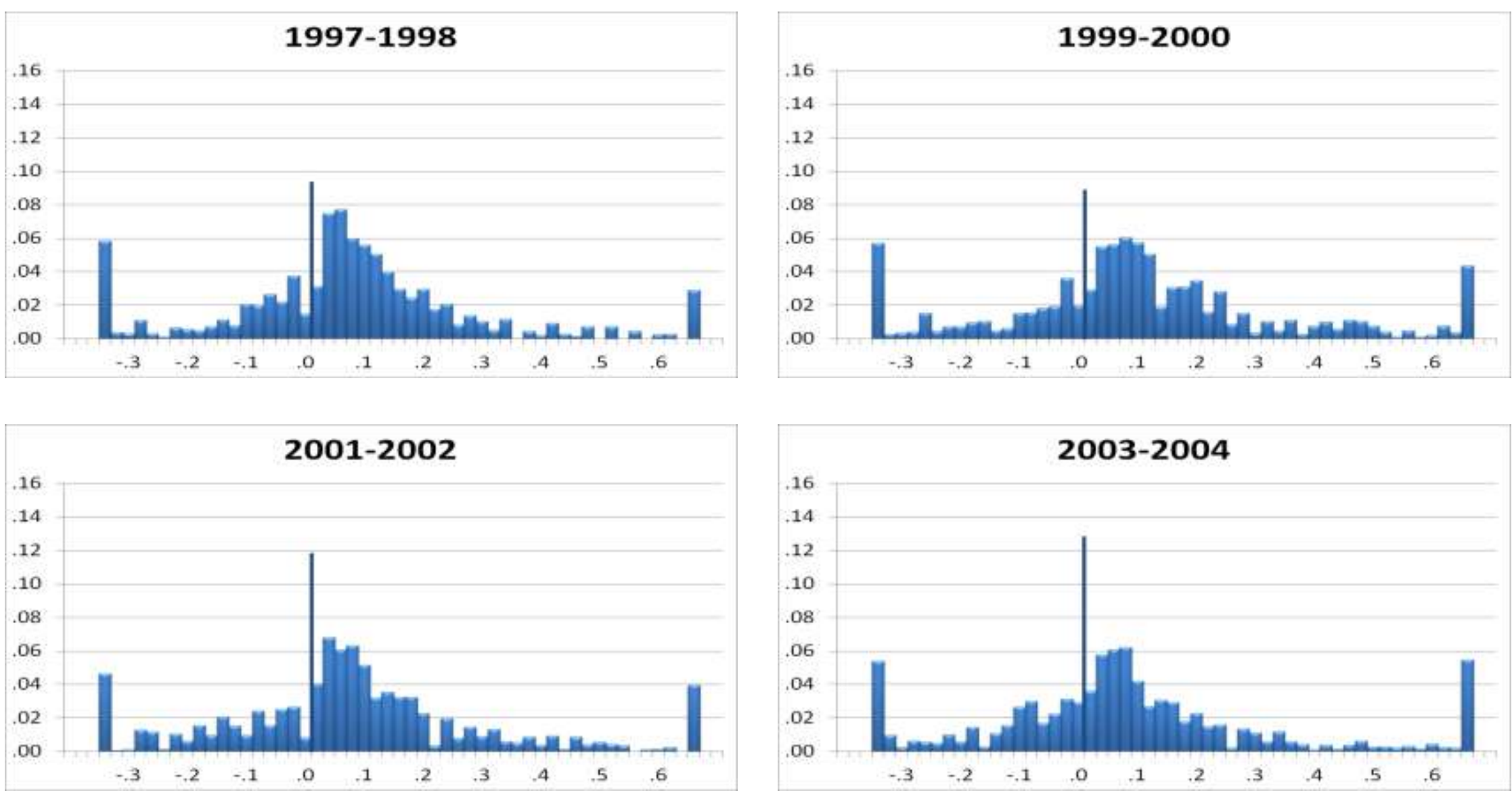
Figure 6 continued
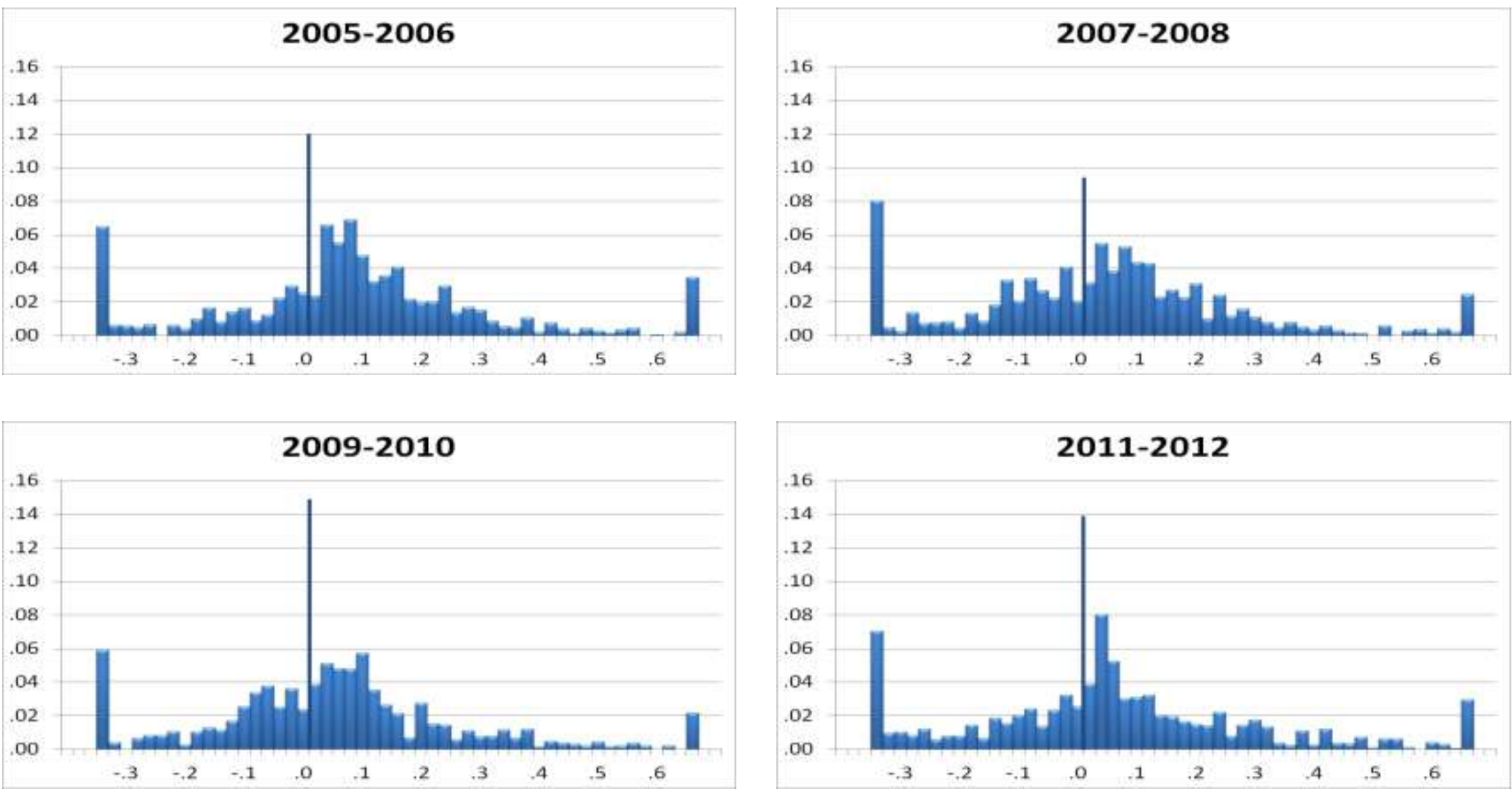
Figure 7. Unemployment and Inflation in the United Kingdom, 1975 to 2012

\section{A. Unemployment Rate}

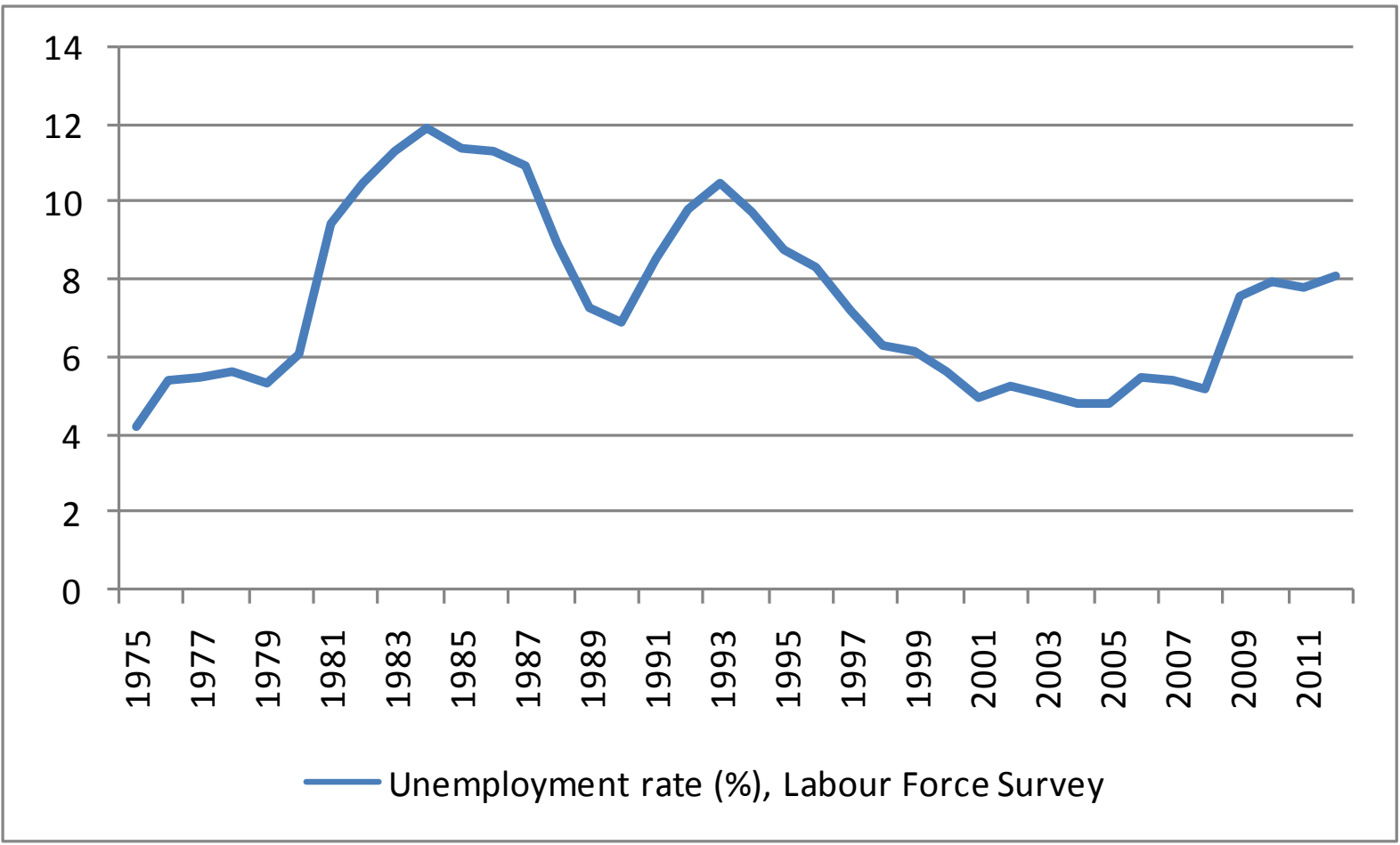

\section{B. Inflation Rate}

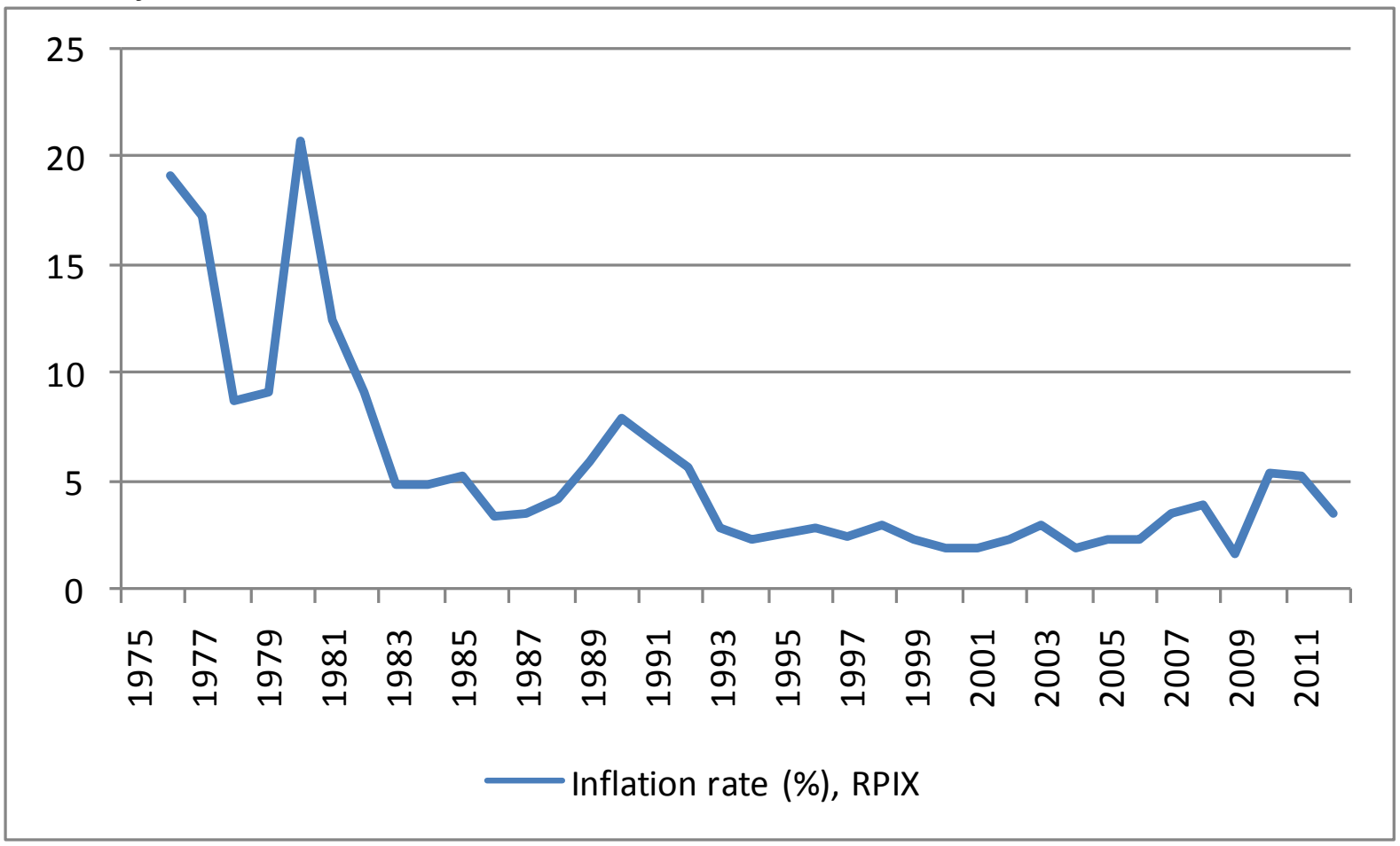

Note: In line with the timing of the NES, both series report April-to-April data. 
Figure 8. Mean Log Real Wages (2012 Pounds) in Great Britain, 1975 to 2011

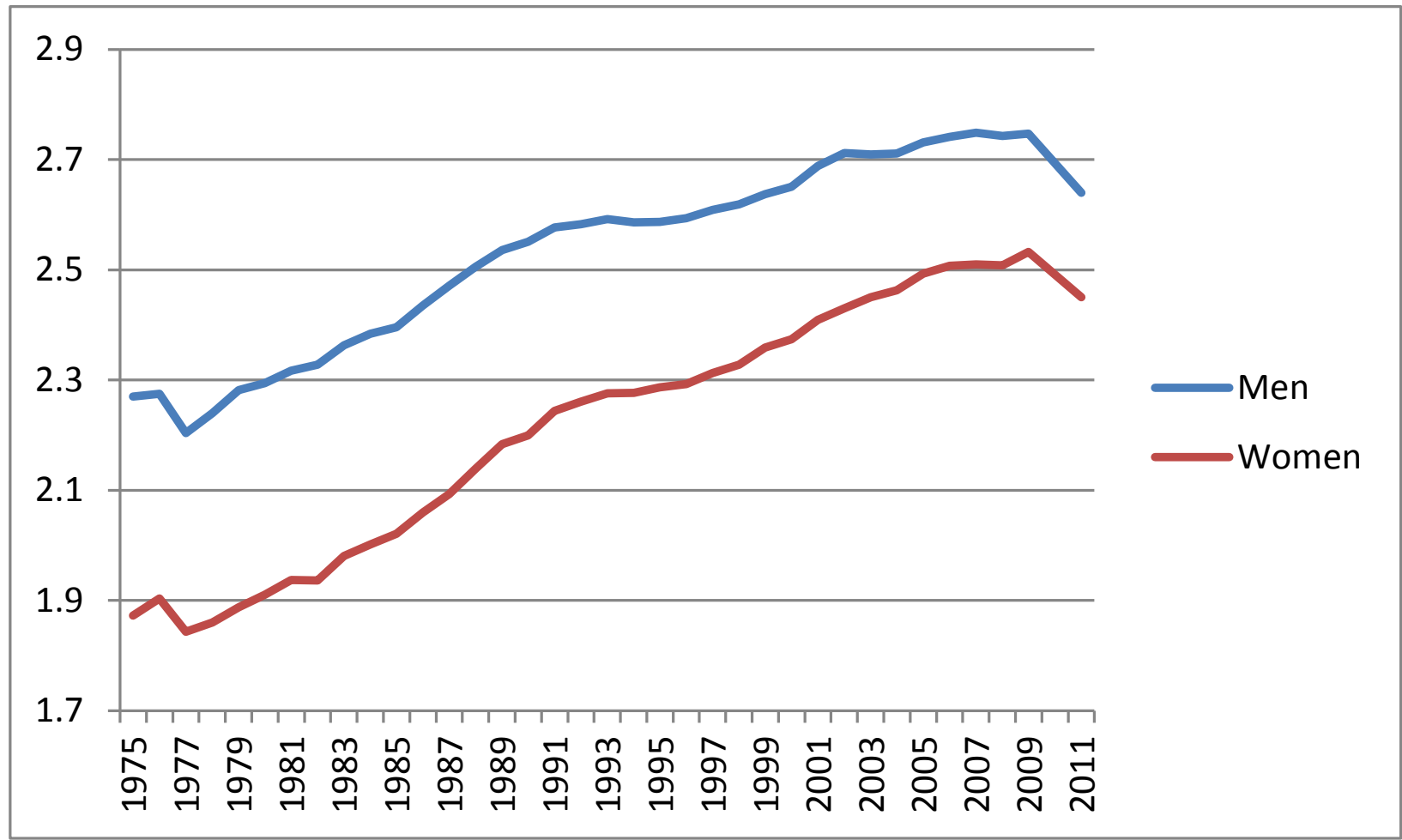

Notes: Mean log hourly earnings excluding overtime, deflated using the RPIX series, for individuals aged 25 to 59 , excluding the top and bottom one percent of hourly earnings. 
Figure 9. Mean Log Real Wage Changes in Great Britain, 1975 to 2011

\section{A. Men}

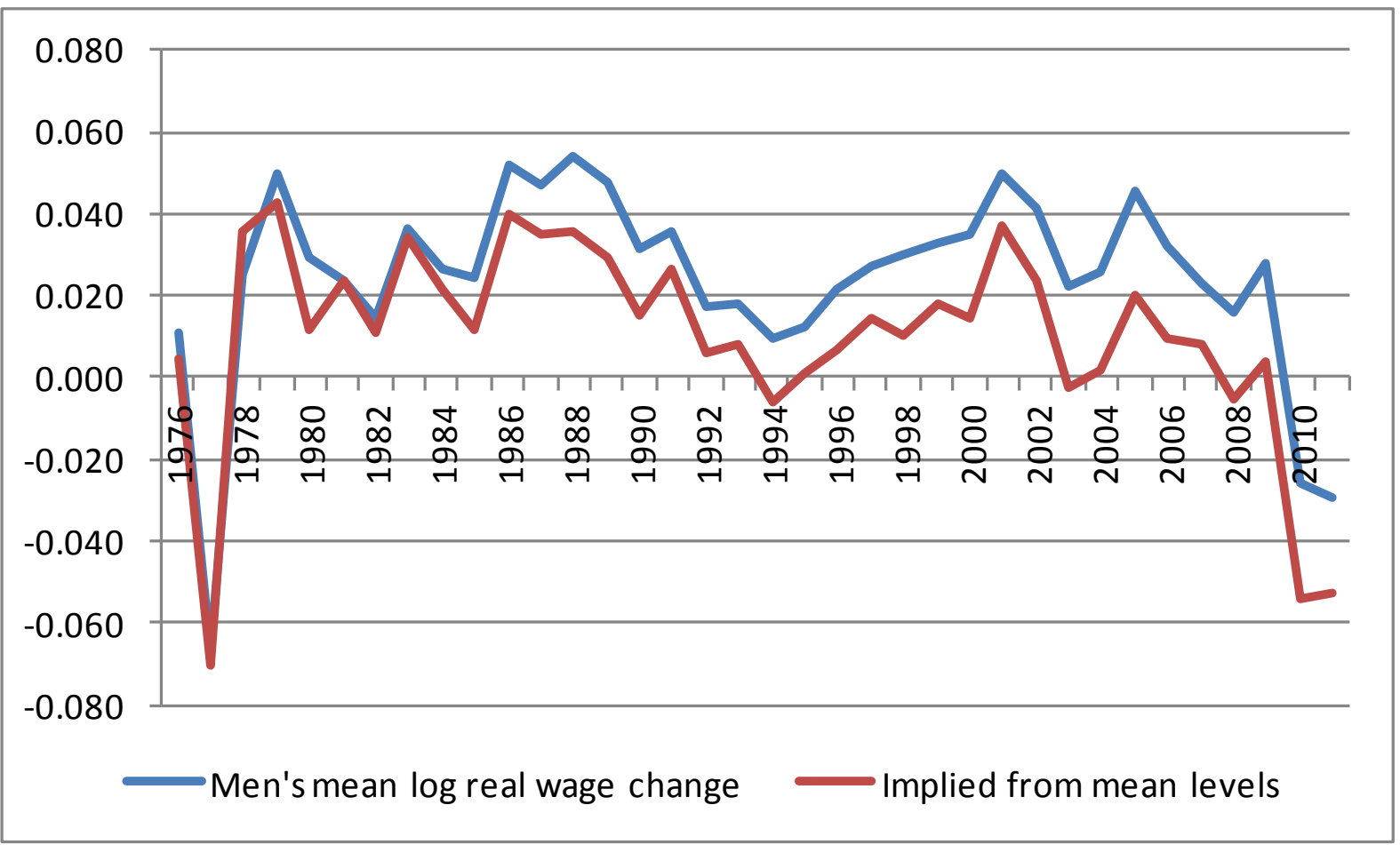

\section{B. Women}

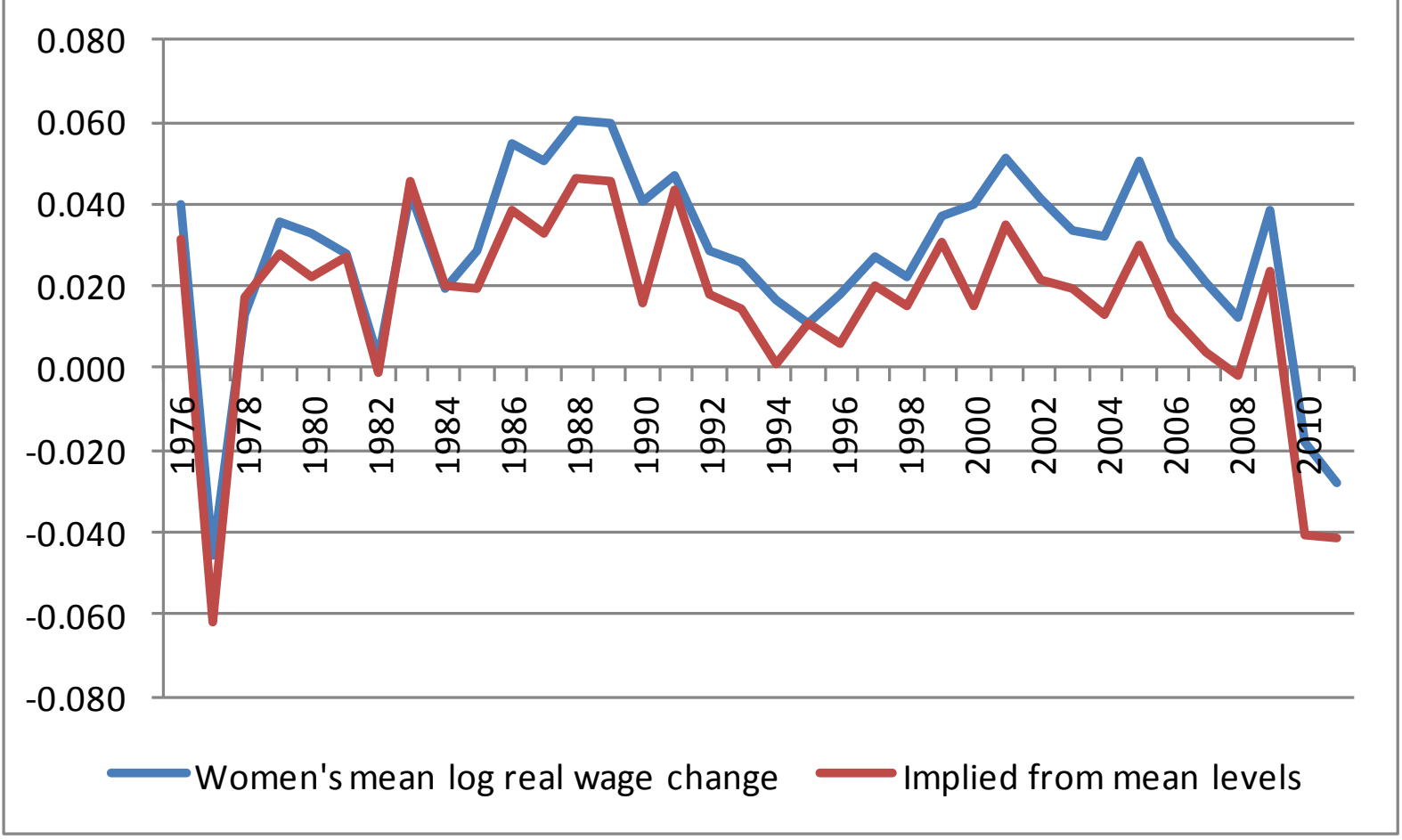


Figure 10. Mean Changes in Log Real Wages in Great Britain Disaggregated by Union Status
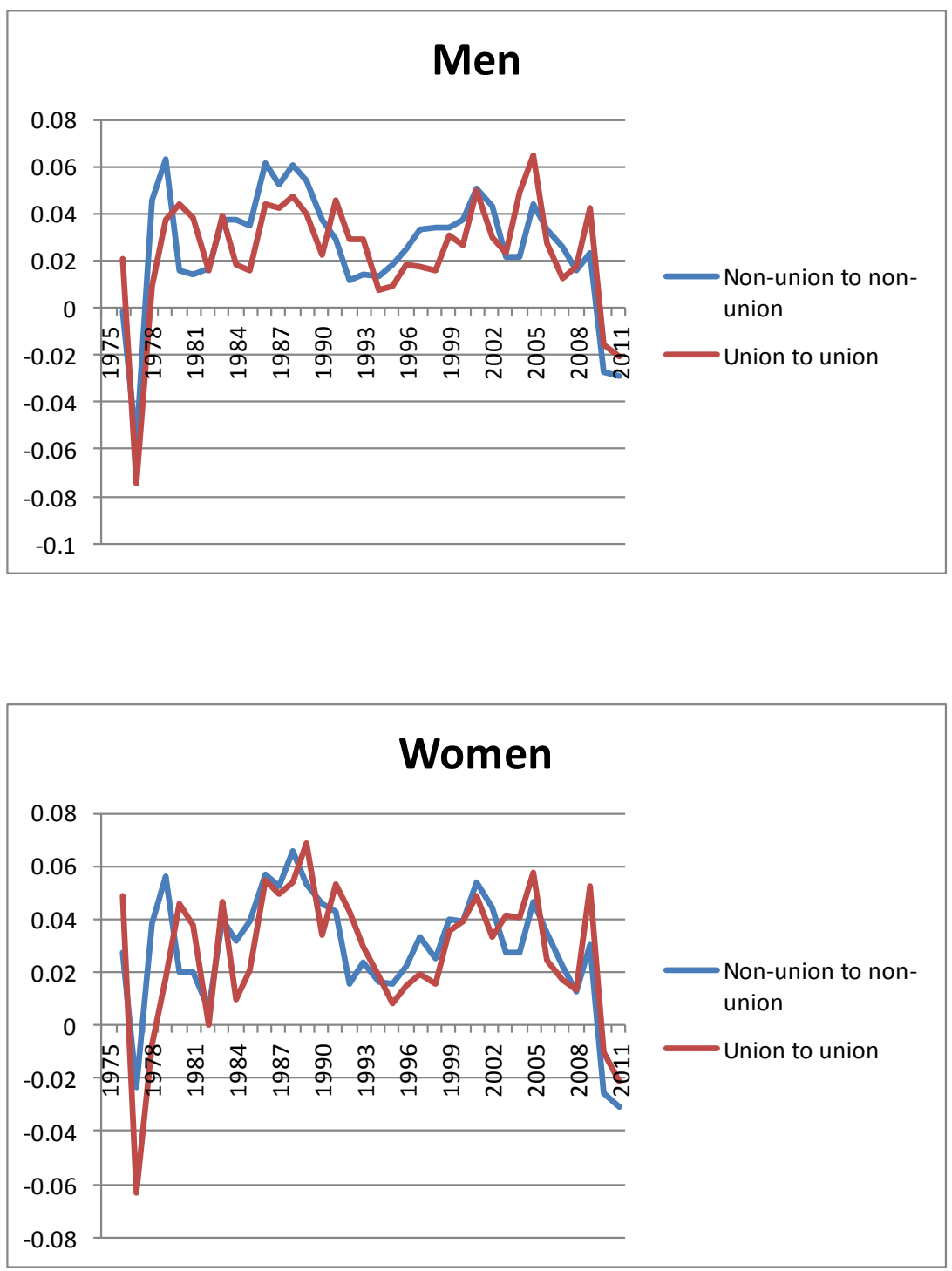
Figure 11. Distributions of Year-to-Year Change in Log Nominal Hourly Wages for British Job Stayers
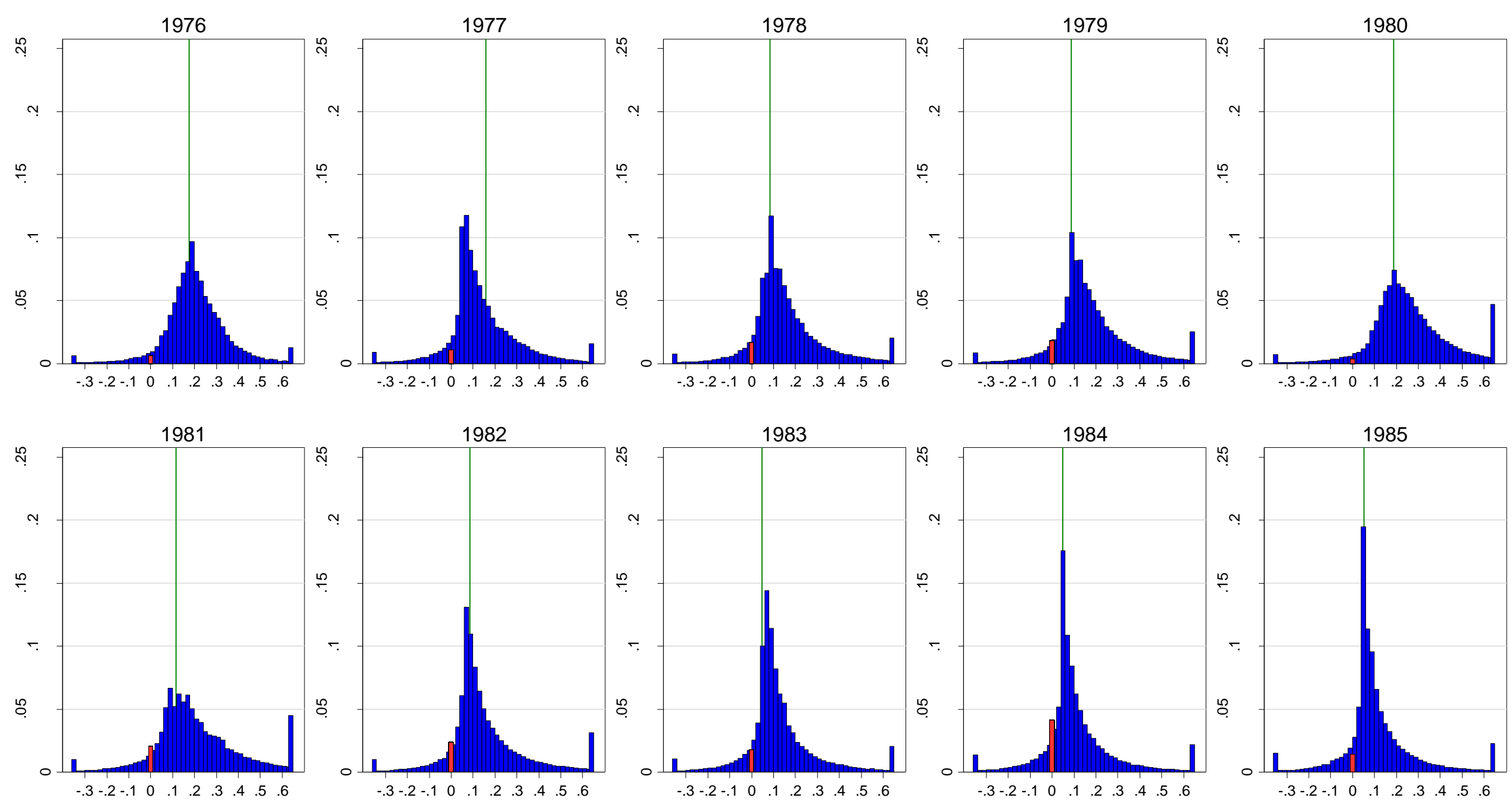
Figure 11 continued
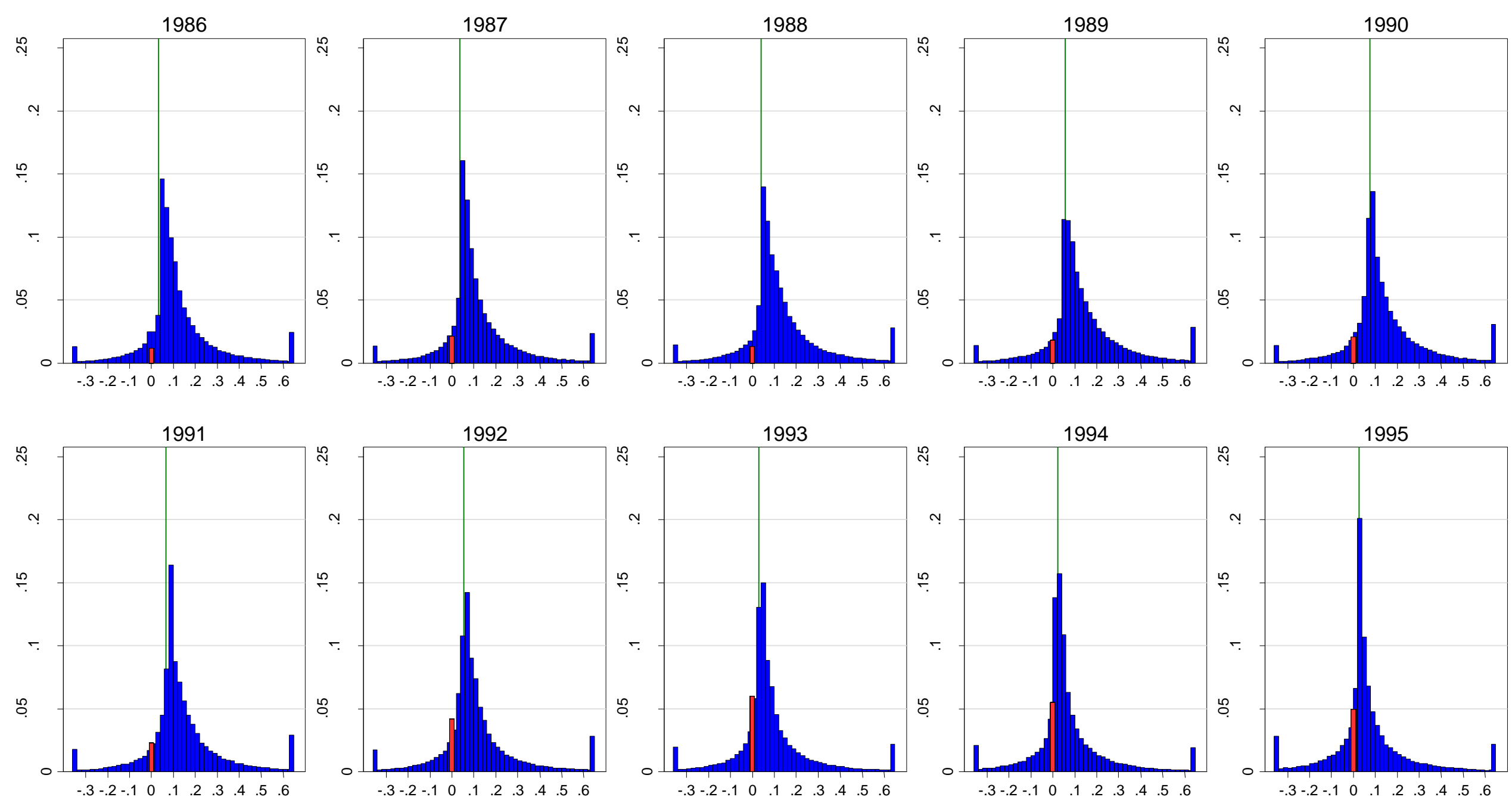
Figure 11 continued
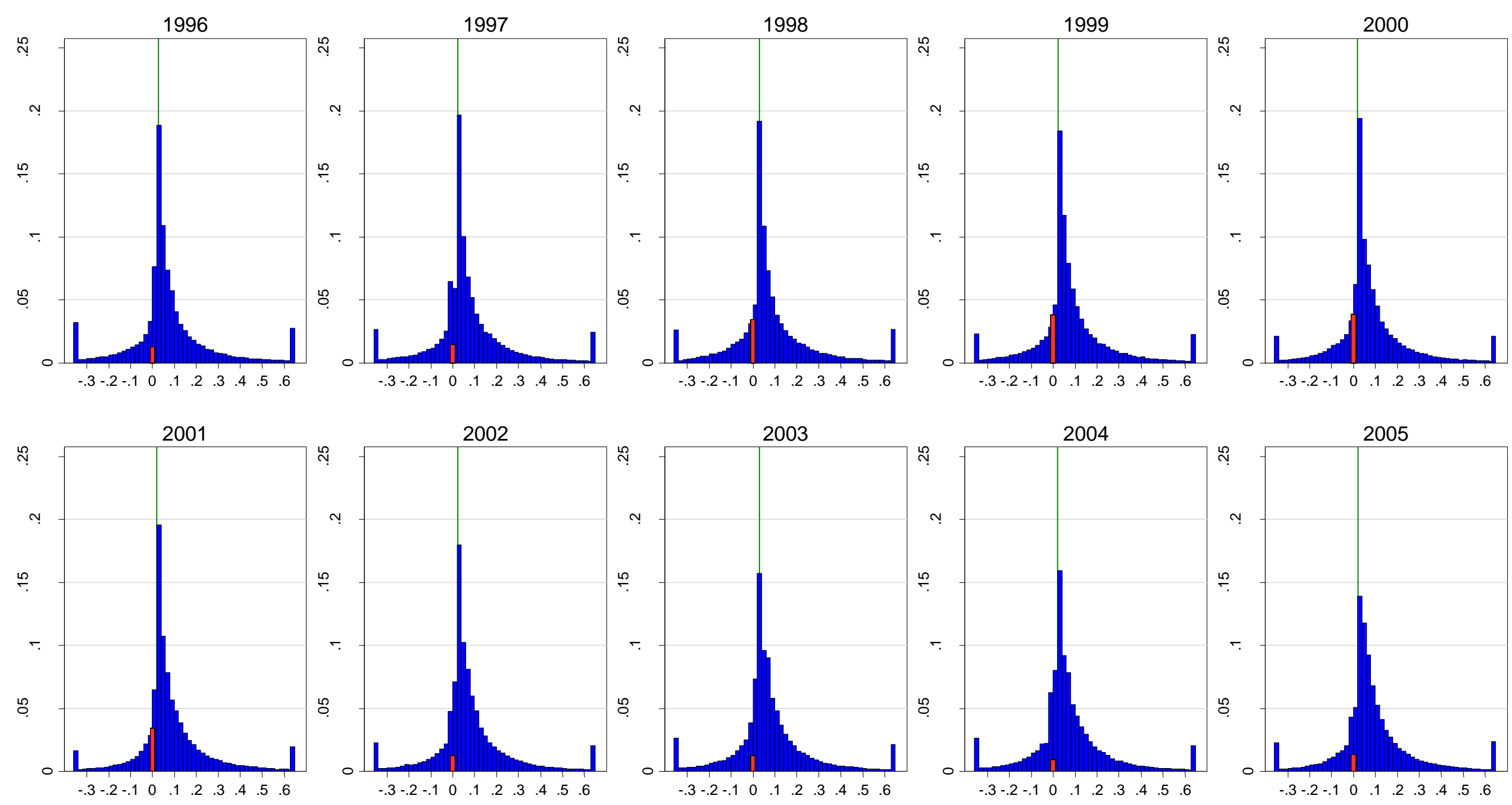

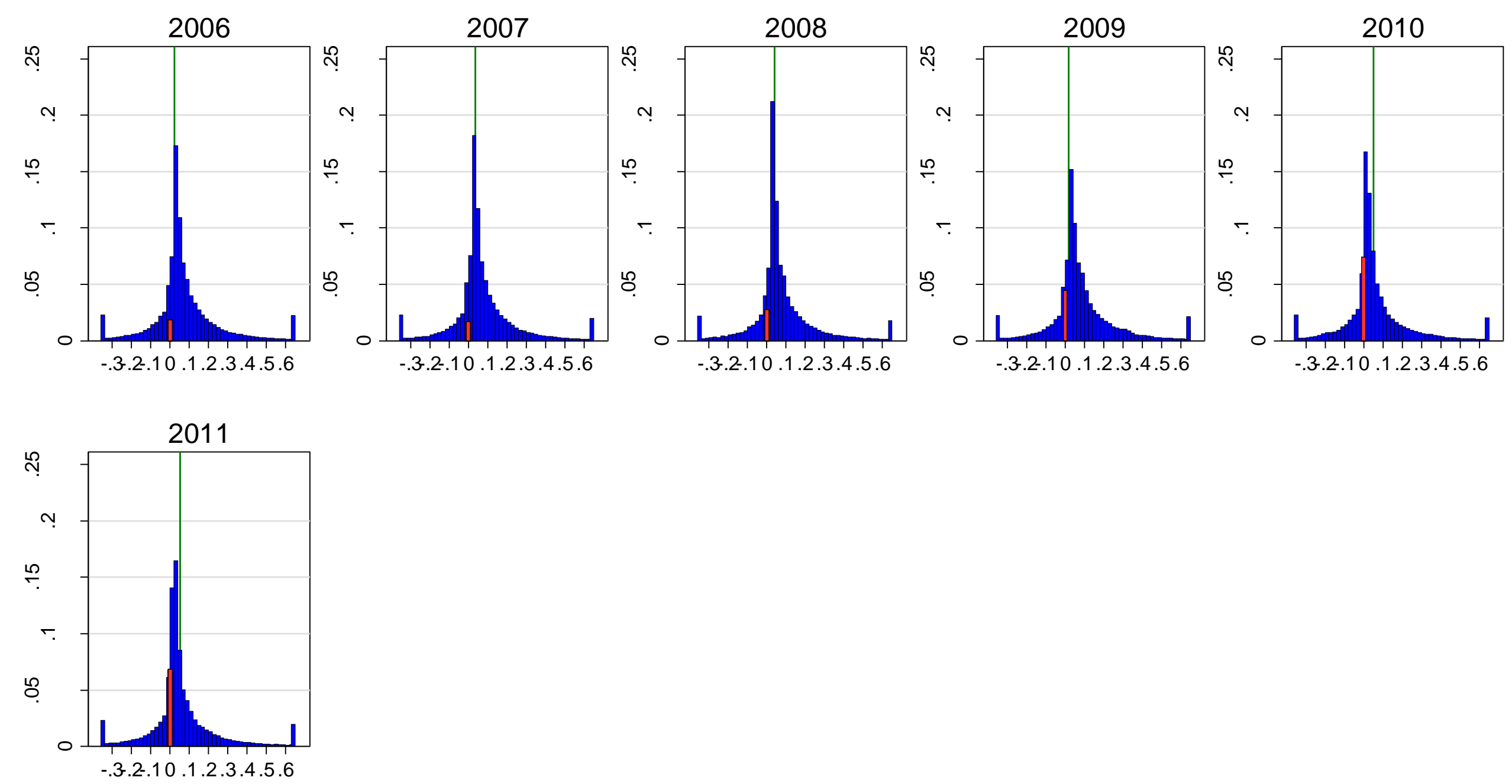


\section{$\underline{\text { References }}$}

Altonji, Joseph G., and Paul J. Devereux. 1999. "The Extent and Consequences of Downward Wage Rigidity.” Working Paper No. 7236, National Bureau of Economic Research.

Beaudry, Paul, and John DiNardo. 1991. "The Effect of Implicit Contracts on the Movement of Wages over the Business Cycle: Evidence from Micro Data.” Journal of Political Economy, 99(4): 665-88.

Becker, Gary S. 1962. "Investment in Human Capital: A Theoretical Analysis.” Journal of Political Economy, 70(5): S9-49.

Bewley, Truman F. 1999. Why Wages Don't Fall during a Recession. Cambridge, MA: Harvard University Press.

Bils, Mark J. 1985. "Real Wages over the Business Cycle: Evidence from Panel Data.” Journal of Political Economy, 93(4): 666-89.

Blinder, Alan S., and Don H. Choi. 1990. "A Shred of Evidence on Theories of Wage Stickiness.” Quarterly Journal of Economics, 105(4): 1003-15.

Blundell, Richard, Claire Crawford, and Wenchao Jin. 2013. "What Can Wages and Employment Tell Us about the UK's Productivity Puzzle?” Working Paper No. 13/11, Institute for Fiscal Studies.

Bowlus, Audra, Haoming Liu, and Chris Robinson. 2002. "Business Cycle Models, Aggregation, and Real Wage Cyclicality.” Journal of Labor Economics, 20(2): 308-35.

Card, David, and Dean Hyslop. 1996. "Does Inflation 'Grease the Wheels of the Labor Market?" Working Paper No. 5538, National Bureau of Economic Research.

Carneiro, Anabela, Paulo Guimarães, and Pedro Portugal. 2012. "Real Wages and the Business Cycle: Accounting for Worker, Firm, and Job Title Heterogeneity.” American Economic Journal: Macroeconomics, 4(2): 133-52.

Daly, Mary, Bart Hobijn, and Brian Lucking. 2012. "Why Has Wage Growth Stayed Strong?" Federal Reserve Bank of San Francisco Economic Letter No. 2012-10.

Devereux, Paul J. 2001. "The Cyclicality of Real Wages within Employer-Employee Matches." Industrial and Labor Relations Review, 54(4): 835-50.

Devereux, Paul J., and Robert A. Hart. 2006. "Real Wage Cyclicality of Job Stayers, WithinCompany Job Movers, and Between-Company Job Movers.” Industrial and Labor Relations Review, 60(1): 105-19. 
Elsby, Michael W. L. 2009. "Evaluating the Economic Significance of Downward Nominal Wage Rigidity." Journal of Monetary Economics, 56(2): 154-69.

Elsby, Michael W. L., Bart Hobijn, and Ayşegül Şahin. 2010. "The Labor Market in the Great Recession." Brookings Papers on Economic Activity, 2010(1): 1-48.

Farber, Henry S. 2008. "Employment Insecurity: The Decline in Worker-Firm Attachment in the United States.” Working Paper No. 530, Industrial Relations Section, Princeton University.

Gertler, Mark, and Antonella Trigari. 2009. "Unemployment Fluctuations with Staggered Nash Wage Bargaining.” Journal of Political Economy, 117(1): 38-86.

Hall, Robert E. 2005. "Employment Fluctuations with Equilibrium Wage Stickiness." American Economic Review, 95(1): 50-65.

Hall, Robert E., and Paul R. Milgrom. 2008. "The Limited Influence of Unemployment on the Wage Bargain.” American Economic Review, 98(4): 1653-74.

Jaeger, David A. 1997. "Reconciling the Old and New Census Bureau Education Questions: Recommendations for Researchers." Journal of Economic and Business Statistics, 15(3): 300-9.

Kahn, Shulamit. 1997. "Evidence of Nominal Wage Stickiness from Microdata." American Economic Review, 87(5): 993-1008.

Kennan, John. 2010. "Private Information, Wage Bargaining and Employment Fluctuations." Review of Economic Studies, 77(2): 633-64.

Keynes, John Maynard. 1936. The General Theory of Employment, Interest, and Money. London: Macmillan.

Kudlyak, Marianna. 2009. "The Cyclicality of the User Cost of Labor with Search and Matching." Working Paper No. 09-12, Federal Reserve Bank of Richmond.

Madrian, Brigitte C., and Lars John Lefgren. 2000. "An Approach to Longitudinally Matching Current Population Survey (CPS) Respondents.” Journal of Economic and Social Measurement, 26(2000): 31-62.

Martins, Pedro S., Gary Solon, and Jonathan P. Thomas. 2012. "Measuring What Employers Do about Entry Wages over the Business Cycle: A New Approach.” American Economic Journal: Macroeconomics, 4(4): 36-55. 
McLaughlin, Kenneth. 1994. "Rigid Wages?” Journal of Monetary Economics, 34(3): 383414.

Mortensen, Dale T., and Christopher A. Pissarides. 1994. "Job Creation and Job Destruction in the Theory of Unemployment." Review of Economic Studies, 61(3): 397-415.

Nickell, Stephen, and Glenda Quintini. 2003. "Nominal Wage Rigidity and the Rate of Inflation.” Economic Journal, 113(490): 762-81.

Office for National Statistics, New Earnings Survey Panel Dataset, 1975-2011: Secure Access [computer file]. $2^{\text {nd }}$ Edition. Colchester, Essex: UK Data Archive [distributor], October 2012. SN: 6706.

Shimer, Robert. 2004. "The Consequences of Rigid Wages in Search Models." Journal of the European Economic Association, 2(2-3): 469-79.

Shin, Donggyun. 2012. "Cyclicality of Real Wages in Korea." B.E. Journal of Economic Analysis and Policy (Contributions), 12(1): Article 2.

Shin, Donggyun, and Gary Solon. 2007. "New Evidence on Real Wage Cyclicality within Employer-Employee Matches." Scottish Journal of Political Economy, 54(5): 648-60.

Smith, Jennifer C. 2000. "Nominal Wage Rigidity in the United Kingdom.” Economic Journal, 110(462): C176-95.

Snell, Andy, and Jonathan P. Thomas. 2010. "Labor Contracts, Equal Treatment, and WageUnemployment Dynamics." American Economic Journal: Macroeconomics, 2(3): 98127.

Solon, Gary, Robert Barsky, and Jonathan A. Parker. 1994. "Measuring the Cyclicality of Real Wages: How Important Is Composition Bias?” Quarterly Journal of Economics, 109(1): $1-25$.

Stockman, Alan C. 1983. "Aggregation Bias and the Cyclical Behavior of Real Wages.” Unpublished manuscript. 